Georgetown University Law Center

Scholarship @ GEORGETOWN LAW

2017

\title{
Making News: Balancing Newsworthiness and Privacy in the Age of Algorithms
}

\author{
Erin C. Carroll \\ Georgetown University Law Center, ecc66@law.georgetown.edu
}

This paper can be downloaded free of charge from:

https://scholarship.law.georgetown.edu/facpub/1877

https://ssrn.com/abstract=2877335

106 Geo. L.J. 69 (2017)

This open-access article is brought to you by the Georgetown Law Library. Posted with permission of the author. Follow this and additional works at: https://scholarship.law.georgetown.edu/facpub

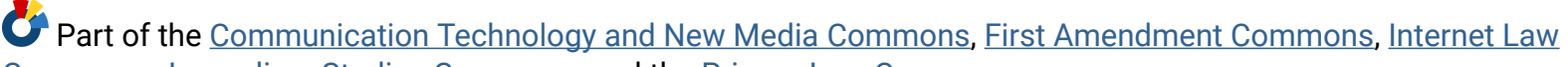
Commons, Journalism Studies Commons, and the Privacy Law Commons 


\title{
Making News: Balancing Newsworthiness and Privacy in the Age of Algorithms
}

\author{
ERIN C. CARROLL*
}

\section{TABLe of ConTEnTS}

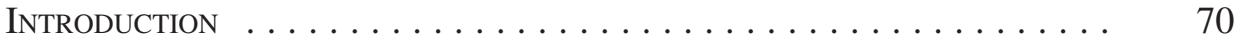

I. Privacy v. First Amendment: The Development of Deference TO THE PRESS ....................... 74

A. WARREN, BRANDEIS, PROSSER, AND THE EVOLUTION OF

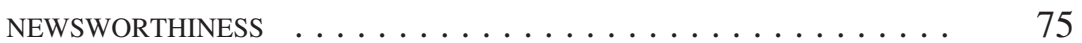

B. NEWSWORTHINESS AND THE COURTS' DEFERENCE TO THE

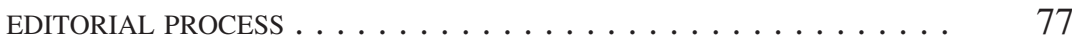

II. The Role of Algorithms in Defining Newsworthiness _ . . . . 81

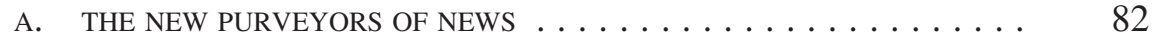

B. THE “LIMINAL PRESS”: ALGORITHMS AND THEIR CREATORS . . . . 87

C. NEWS JUDGMENT AND THE FOURTH ESTATE: JOURNALISM'S

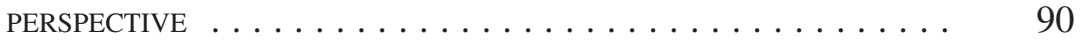

III. The Impact of a Change in GateKeeper . . . . . . . . . . . . . . . . 95

IV. Rethinking Newsworthiness: Balancing Privacy and the First

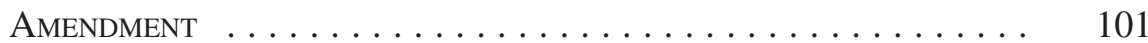

A. BEYOND ALGORITHMS: WHY SWEEPING DEFERENCE IS NOT JUSTIFIED .......................... 102

B. SALVAGING NEWSWORTHINESS: A DEFINITIONAL APPROACH . . . . 105

C. TOWARDS NEW PROCESSES FOR DETERMINING NEWSWORTHINESS $\ldots \ldots$

ConcLusion $\ldots \ldots \ldots \ldots \ldots \ldots \ldots \ldots \ldots \ldots \ldots \ldots \ldots \ldots \ldots \ldots \ldots \ldots \ldots$

* Associate Professor of Legal Research and Writing, Georgetown University Law Center. ( $) 2017$, Erin C. Carroll. I would like to thank Evan Halper, Paul Ohm, Tom Rosenstiel, Julie Ross, Suzanne Rowe, Rima Sirota, and David Vladeck for their invaluable thoughts at various stages of the writing of this Article. I am especially indebted to Jeffrey Shulman, who read and commented on this Article more times than was fair and offered fresh and important insights each time. I am also grateful to the editors of The Georgetown Law Journal for their thoughtful comments and questions and to Georgetown University Law Center for the grants that made this Article possible. 


\section{INTRODUCTION}

Until recently, the "Page One" meeting was a newspaper ritual. ${ }^{1}$ Top brass gathered around a conference room table to decide what the news of the day was. Editors of political, metro, features, and sports sections pitched stories to the editor in chief, managing editor, and each other. They questioned and debated. $^{2}$ Skepticism abounded. When it was all over, section editors had marching orders for their reporters, and everyone knew what would appear on page A1. When it was done right, the editors around the table had made decisions based on their collective news sense - the product of their journalistic training, experience, and professional ethics. The stories that survived the gauntlet had been deemed newsworthy. ${ }^{3}$

These days, editorial meetings still happen, and the questioning and debating continue. ${ }^{4}$ But the emphasis has shifted. Given that news is far more often consumed on phones than broadsheets of newsprint, the "Page One" label has fallen into disuse. ${ }^{5}$ At today's meeting, editors needing to generate sufficient reader traffic to websites are often more concerned with clicks and "engagement" than with what will appear on A1. Moreover, the editors in that meeting no longer dictate to the same degree what news we actually read. That determination is ever more in the hands of computer engineers in Silicon Valley. These engineers design and continually recalibrate the algorithms that populate the

1. The "Page One" meeting is the name used by The New York Times. See Kyle Massey, The Old Page 1 Meeting, R.I.P.: Updating a Times Tradition for the Digital Age, N.Y. Times (May 12, 2015, 2:33 PM), http://www.nytimes.com/times-insider/2015/05/12/the-old-page-1-meeting-r-i-p-updating-atimes-tradition-for-the-digital-age/ [https://nyti.ms/2lvekAU]. Other publications or news outlets may use other terms, such as the "morning meeting" or the "Daily Editorial Meeting," but the concept is the same. See, e.g., Nu Yang, The Evolving Newsroom, Editor \& Publisher (July 18, 2014), http://www. editorandpublisher.com/news/the-evolving-newsroom/ [https://perma.cc/D6EA-MYJS] (describing The Des Moines Register's morning meeting).

2. Editorial Meetings, BBC: ACAD., http://www.bbc.co.uk/academy/journalism/article/art2013070211 2133495 [https://perma.cc/RKC4-MKF7] (describing the debate that occurs in an editorial meeting).

3. See Massey, supra note 1 (quoting a note from The New York Times executive editor Dean Baquet to staff about changes to the Page One meeting that "stories and photos that appear on Page 1 reflect our collective judgment about the most important journalism we are offering to our readers each day").

4. In 2015, The New York Times executive editor Dean Baquet discontinued the "Page One" meeting, and replaced it "with a 9:30 a.m. meeting to discuss how the biggest stories of the day should be covered and promoted digitally." See Joe Pompeo, New York Times Braces for Big Change, PoLITICO (June 28, 2016, 6:06 AM), http://www.politico.com/media/story/2016/06/new-york-times-braces-for-bigchange-004630 [https://perma.cc/VU2A-QVH2]. Editors now discuss the front-page layout at a 3:30 p.m. meeting. Id. Of course, the morning news meeting is not unique to The New York Times. See, e.g., Kristen Hare, At The Dallas Morning News, Becoming Truly Digital Means Starting Over, PoYNTER (Mar. 9, 2016), http://www.poynter.org/2016/at-the-dallas-morning-news-becoming-truly-digital-meansstarting-over/400041/ [https://perma.cc/K6QK-24H6] (describing how the morning news meeting has changed to adjust to a digital environment including that participants now engage in an assessment of social media analytics).

5. See Amy Mitchell et Al., The Modern News Consumer 4 (2016), http://www.journalism.org/2016/ 07/07/the-modern-news-consumer/ [https://perma.cc/M95C-G7GY] (indicating about four-in-ten Americans often get their news online and only two-in-ten often get it from print newspapers). 
feeds of information on social media platforms. ${ }^{6}$ It is on these platforms that Americans increasingly find news.

Computer engineers are, by definition, not journalists. Their employers, companies like Facebook, Google, and Twitter, are platforms, not media companies. ${ }^{7}$ They are not in the business of generating journalism, which involves vetting material for truth, aspiring to accuracy and objectivity, and determining the relative social significance of news. Rather, their aim is perfecting algorithms to discern exactly what it is that we want to read and to give us just that, regardless of its objective value or importance. That may mean taking into account what Facebook CEO Mark Zuckerberg once reportedly told an audience: "[A] squirrel dying in your front yard may be more relevant to your interests right now than people dying in Africa." ${ }^{8}$ Of late, it has also meant the emergence of "fake news" created by opportunists looking to profit or even, as some have alleged, influence politics. ${ }^{9}$

As the role of information gatekeeper starts to pass from journalists at legacy news organizations to engineers, coders, and designers, the very nature of the Fourth Estate and the news it produces is changing. While their aspirations may be sweeping, platform executives have not indicated a desire to be a Fourth Estate-an "informal or extraconstitutional fourth branch" of government that has "exposed public mismanagement and kept power fragmented, manageable, and accountable." 10 As Emily Bell, director of the Tow Center for Digital Journalism at the Columbia University Graduate School of Journalism, has

6. See Tarleton Gillespie, The Relevance of Algorithms, in Media Technologies: Essays on CommuniCation, Materiality, and Society 167, 178 (Gillespie et al. eds., 2014) (“[T]he workings of the algorithm [for Facebook] are both obscured and malleable, likely so dynamic that a snapshot of them would give us little chance of assessing their biases." (internal quotations omitted)); Victor Luckerson, Here's How Facebook's News Feed Actually Works, TIME (July 9, 2015), http://time.com/3950525/ facebook-news-feed-algorithm/ [https://perma.cc/2BRC-NYCQ]; Will Oremus, Who Controls Your Facebook Feed, SLATE (Jan. 3, 2016), http://www.slate.com/articles/technology/cover_story/2016/01/how_ facebook_s_news_feed_algorithm_works.html [https://perma.cc/9F2G-XP8J] (describing algorithms as "a set of concrete instructions by which a given problem may be solved").

7. See Jeffrey Herbst, The Algorithm Is an Editor, WALL ST. J. (Apr. 13, 2016), https://www.wsj.com/ articles/the-algorithm-is-an-editor-1460585346\# [https://perma.cc/F2TS-6F66] ("Tech companies are adamant that they are not news providers but simply distribution networks. In a recent interview with Business Insider, Facebook's Mark Zuckerberg said, 'I think the platform is the core of our product that people use to share and consume media, but we ourselves are not a media company.'”). There is some suggestion that this is changing, at least with respect to Twitter. See Jordan Valinsky, Twitter Now Bills Itself as a News App, Not a Social Network, DigIDAY (Apr. 28, 2016), http://digiday.com/platforms/twitternews-app-store/ [https://perma.cc/ECQ7-ZC6B]. In April 2016, Twitter was re-categorized to "News" from the "Social Networking" category in the Apple App Store. Id. There was speculation, however, that this was done to boost its rating from sixth place in the latter category to first place in the former. Id.

8. Eli Pariser, When the Internet Thinks It Knows You, N.Y. Times (May 22, 2011), http://www.nytimes. com/2011/05/23/opinion/23pariser.html [https://nyti.ms/2kta833].

9. Andrew Higgins et al., Inside a Fake News Sausage Factory: 'This Is All About Income,' N.Y. Times (Nov. 25, 2016), https://www.nytimes.com/2016/11/25/world/europe/fake-news-donald-trumphillary-clinton-georgia.html [https://nyti.ms/2jAGJH3].

10. Leonard W. Levy, Emergence of a Free Press 273 (1985). 
written, "The people who built these platform companies did not set out to do so in order to take over the responsibilities of a free press. In fact, they are rather alarmed that this is the outcome of their engineering success." 11

This success has significant implications for the law and for privacy law in particular. Courts have long been deferential to the press, especially in tort cases accusing media companies of violating individuals' privacy. ${ }^{12}$ In invasion of privacy lawsuits, media defendants usually wrap themselves in the First Amendment and defend the "newsworthiness" of the allegedly private fact. ${ }^{13}$ And in case after case, the newsworthiness defense has protected the press. Courts have rejected the role of super-editor, indicating that they do not want to secondguess the institution that is in the business of deciding what the news is. ${ }^{14}$ The result has been an almost "talismanic immunity" for the press: the quick disposition of cases, avoidance of difficult line drawing, and broad First Amendment protections. ${ }^{15}$

But given the changes in how news is created and distributed, including the prevalence of algorithms in determining what we read, should newsworthiness be determined by the modern-day corollary - a glance at our Facebook News Feeds? If social media companies-guided by algorithms (formulas for decision making) rather than journalists - are becoming "the dominant news providers for many Americans," is this degree of deference to content published as "news" still warranted? ${ }^{16}$

This Article's answer is no. Given the sweeping changes to the Fourth Estate ${ }^{17}$ courts need to be wary of knee-jerk deference that is rooted in an

11. Emily Bell, Facebook is Eating the World, Colum. Journalism Rev. (Mar. 7, 2016), http://www. cjr.org/analysis/facebook_and_media.php [https://perma.cc/V39P-ASY2].

12. See Danielle Keats Citron, Mainstreaming Privacy Torts, 98 Calif. L. Rev. 1805, 1828-29 (2010) (noting that courts "often defer to the media's judgment" and citing a dated but relevant study that found "from 1974 to 1984 , plaintiffs prevailed in $2.8 \%$ of cases involving public disclosure claims against the media and in twelve percent of cases involving non-media defendants").

13. See Publishing Highly Personal and Embarrassing Information About Another, Even If Completely True, REP. COMMITTEE FOR FREEDOM OF THE PRESs, http://www.rcfp.org/browse-media-law-resources/ digital-journalists-legal-guide/publishing-highly-personal-and-embarrassi [https://perma.cc/4BHY-FZ2B] (noting that "[b]ecause newsworthiness is a defense to private-facts claims, you can help protect yourself from liability by publicizing matters that are newsworthy").

14. See, e.g., Ross v. Midwest Commc'ns, Inc., 870 F.2d 271, 275 (5th Cir. 1989) (noting "judges, acting with the benefit of hindsight, must resist the temptation to edit journalists aggressively").

15. See Neil M. Richards \& Daniel J. Solove, Prosser's Privacy Law: A Mixed Legacy, 98 CALIF. L. REv. 1887, 1918 (2010) ("A number of courts are very deferential to the media on newsworthiness, essentially concluding that if the media chooses to publish a story, then this is the most viable evidence of its newsworthiness .... Such an approach virtually nullifies the [public disclosure of private facts] tort in the media context."). The phrase "talismanic immunity" was used by Justice Brennan in his majority opinion in New York Times Co. v. Sullivan, although it was to describe the limits on libel law. See 376 U.S. 254, 269 (1964).

16. See Herbst, supra note 7 ("Social media companies quickly are becoming the dominant news providers for many Americans and citizens across the world. The implications of this revolution are significant for how we understand the information ecosystem and our democracy.").

17. Lucas A. Powe, Jr., The Fourth Estate and the Constitution: Freedom of the Press in America 233-34 (1991) (explaining the term "Fourth Estate" is attributed to Edmund Burke, an eighteenth- 
increasingly outdated assumption that an institutional press has necessarily acted according to a set of professional guidelines and ethics. It is becoming a relic of a time in the not-so-distant past when the Fourth Estate served as both generator and distributor of content-a time when it had a near monopoly on the information gatekeeper role. Today, a rift is growing between how the press generates news and how the courts seem to assume this task is accomplished. Courts need to better understand the forces at work behind what we are consuming as news and adjust their decision making accordingly. In doing this, if we truly want to give heft to the privacy torts as they now exist, courts may need to play the role they have assiduously avoided - the role of editor.

This Article proposes that instead of exercising deference to the press as a reflex and dismissing cases against the media at an early stage, the law should place a burden on media defendants. They would need to prove two things. First, media defendants would need to show they engaged in the process the courts have typically assumed has occurred-assessing newsworthiness before deciding to publish. Second, given that the First Amendment provides the theoretical underpinning for the newsworthiness defense, media defendants would need to demonstrate the publication of the allegedly private fact had First Amendment value-for example, a dialogue-building or watchdog function. ${ }^{18}$

If a media defendant could not offer up this proof, newsworthiness would not (as often happens now) be decided as a matter of law. ${ }^{19}$ Instead, the judge or jury, acting as fact-finders, would develop the record so they could be positioned to make well-reasoned decisions regarding newsworthiness. In this way, the deliberative process that was once occurring robustly in newsrooms could now happen in the litigation process. A more intricate process may be able to serve in some way as a surrogate for the Page One editorial meetings of the past. As part of this process, courts should develop a set of factors to help them decide whether to label as legitimately newsworthy the news that is published. Finally, courts should welcome the help of journalists as experts in invasion-ofprivacy cases to better understand and assess whether a news organization exercised editorial decision making in publishing. Moreover, the press's participation in the process would help prevent the newsworthiness decision from becoming a referendum on the bounds of public taste.

In proposing these solutions, there are certain things this Article is not doing. It avoids making normative judgments about the quality of journalism and news

century member of the British House of Commons, and is distinguishable from the other estates, "Lords Spiritual, Lords Temporal, and Commons, which have in modern times been subsumed into one: the government"). In this Article, the terms media, press, and Fourth Estate are used interchangeably.

18. See RonNell Andersen Jones, What the Supreme Court Thinks of the Press and Why It Matters, 66 Ala. L. Rev. 253, 256-59 (2014) (devoting sections to characterizations of the press as educator, dialogue builder, and watchdog).

19. See, e.g., Gaeta v. Home Box Office, 645 N.Y.S.2d 707, 710 (N.Y. Civ. Ct. 1996) (noting that "[n]early all of the reported cases" that had considered the newsworthiness exception to New York's right of privacy law "have been decided as a matter of law" on pre-trial motions). 
today. Rather, it aims to begin to realign privacy-law doctrine to the reality of today's news business. It is also not intended to be a full-throated defense of stronger privacy protections at the expense of the First Amendment. ${ }^{20}$ Rather, it accepts as a baseline that we, as a society, have determined there should be some balance between the two and that we have done a poor job of making this a reality. When it comes to the press, courts' resistance to balancing has come at the expense of those who claim their privacy has been violated. Today, this position is increasingly indefensible. If we want to preserve the public disclosure of private facts tort, there necessarily must be some balancing, and courts need methods for engaging in it. This Article offers some options.

It proceeds in four parts. Part I provides background on the longstanding tension between privacy rights on the one hand and First Amendment rights on the other, with a focus on cases involving the media. In trying to balance the two, courts have repeatedly come down in favor of the press. In doing so, courts have spoken reverently of the editorial process and editorial discretion. Part II gives an overview of the dramatic shift that is underway in how news is distributed and consumed and what we perceive of as news. This includes a discussion of the dissonance between the decision-making processes of engineers, coders, and designers on one hand and journalists on the other. Part III addresses the impact of the shift in the role of information gatekeeper from journalists to engineers, and how platforms and algorithms are not simply funneling news to us, but changing the very nature of what journalists produce. Finally, in Part IV, this Article argues that such broad deference, based on an assumption that news is generally the product of journalists exercising news judgment, is less warranted than it once was. It reviews some changes that scholars have proposed to the public disclosure of private facts tort, including redefining newsworthiness. It then argues that given the inherent slipperiness of newsworthiness, effort may be better spent trying to supplement the loss of editorial discretion with a more robust litigation process, one that would encourage a more careful weighing of privacy and free speech concerns.

\section{Privacy v. First Amendment: The Development of Deference to the Press}

The right to privacy has always risked offending the First Amendment. When in 1890, Samuel Warren and Louis Brandeis published their classic article The Right to Privacy and called for recognition of the right, they recognized the tension between the right to speak and the "right to be let alone." ${ }^{1}$ Seventy years later, in his article Privacy, William L. Prosser called the relationship

20. Others have made this case. See, e.g., Richards \& Solove, supra note 15, at 1922-23 (describing how "tort law must come to a more sophisticated conception of harm," in part to address informational privacy violations).

21. See Samuel D. Warren \& Louis D. Brandeis, The Right to Privacy, 4 Harv. L. Rev. 193, 193, 214-15 (1890) (describing how the right to privacy would not prevent the publication of matters of “public or general interest”); see also Bartnicki v. Vopper, 532 U.S. 514, 534 (2001) (calling The Right to Privacy a "classic"); Fred R. Shapiro \& Michelle Pearse, The Most-Cited Law Review Articles of All 
between privacy and free speech a "head-on collision" that had transitioned to a "slow evolution of a compromise." 22 Today, that compromise is still uneasy. Courts continue to struggle with the concept of newsworthiness, which sits at the crossroads of privacy and the First Amendment, in essence trying to keep the former from violating the latter. ${ }^{23}$ The beneficiary of that struggle, if there is one, has been the press. ${ }^{24}$ In case after case involving the media, courts have struck the balance between privacy and the First Amendment in favor of the press, and in doing so have sweepingly deferred to the Fourth Estate. ${ }^{25}$

\section{A. WARREN, BRANDEIS, PROSSER, AND THE EVOLUTION OF NEWSWORTHINESS}

The media was the catalyst for privacy torts. ${ }^{26}$ Warren and Brandeis's The Right to Privacy could well be described as a diatribe against the media. ${ }^{27}$ In it, they spoke of the "evil of the invasion of privacy by the newspapers" into "the sacred precincts of private and domestic life." 28 Venom practically seeping from the page, they added,

The press is overstepping in every direction the obvious bounds of propriety and of decency. Gossip is no longer the resource of the idle and of the vicious,

Time, 110 Mich. L. Rev. 1483, 1489 (2012) (noting that The Right to Privacy is the second most cited law review article of all time).

22. William L. Prosser, Privacy, 48 CaLIF. L. Rev. 383, 410 (1960).

23. The public disclosure of private facts tort requires "publicity to a matter concerning the private life of another" that "would be highly offensive to a reasonable person" and "is not of legitimate concern to the public." Restatement (SECOND) OF TORTs § 652D (Am. LAW Inst. 1977) (emphasis added). Defamation, too, involves an assessment of the news value of speech, although not as explicitly. A defamatory statement is one published about the plaintiff when the defendant acted either negligently (plaintiff is a private figure) or with actual malice (plaintiff is a public figure). Where newsworthiness inserts itself into the analysis is as a defense. Although it only exists in a limited number of jurisdictions, the neutral reportage privilege can protect a journalist who publishes another person's defamatory statement. See, e.g., Edwards v. Nat'l Audubon Soc., 556 F.2d 113, 120-22 (2d Cir. 1977); see also Neutral Report Privilege, Dig. Media Law ProJect, http://www.dmlp.org/legal-guide/neutralreport-privilege [https://perma.cc/9NMW-5GZU] (noting that the neutral reportage privilege has not been widely adopted). Similarly, the fair report privilege can be employed when a journalist fairly and accurately conveys information from an official public document or statement on a matter of public concern. Fair Report Privilege, Dig. Media L. Project, http://www.dmlp.org/legal-guide/fair-reportprivilege [https://perma.cc/ES7N-LN6U].

24. See Neil M. Richards, Reconciling Data Privacy and the First Amendment, 52 UCLA L. Rev. 1149, 1198 (2005) (describing the Supreme Court's "project of giving the First Amendment preemptive force over tort law").

25. See, e.g., Howell v. N.Y. Post Co., 612 N.E.2d 699, 700-01 (N.Y. 1993) (affirming dismissal of a complaint against a newspaper that published a photograph of plaintiff while she was a patient at a psychiatric hospital); Cape Publ'ns, Inc. v. Bridges, 423 So. 2d 426, 427-28 (Fla. Dist. Ct. App. 1982) (finding newspaper did not violate privacy of woman when it published a photograph of her running from a hostage situation not fully clothed); Lopez v. Triangle Commc'ns, Inc., 421 N.Y.S.2d 57, 58-59 (N.Y. App. Div. 1979) (finding publisher of Seventeen Magazine did not violate privacy of infant when it published a photograph of an infant alongside an article on grooming and makeup tips).

26. See Richards \& Solove, supra note 15, at 1892.

27. See Warren \& Brandeis, supra note 21, at 195-96.

28. Id. at 195. 
but has become a trade.... To satisfy a prurient taste the details of sexual relations are spread broadcast in the columns of the daily papers. ${ }^{29}$

Warren and Brandeis concluded that there was "no doubt" of the desirability and necessity for protection from the media. ${ }^{30}$

Despite their vitriol for the press, Warren and Brandeis also recognized the need for protecting it. Any privacy right, they said, necessarily had to be "limited." 31 Carving out space for the First Amendment was critical, and they indicated that liability for an invasion of privacy would not arise where the media was reporting on a "subject of legitimate interest" to citizens. ${ }^{32}$ Yet, as to where to draw the line between privacy and the First Amendment-in other words, how to define a "subject of legitimate interest" or "newsworthiness"they readily conceded that they had no "wholly accurate or exhaustive definition." ${ }^{33}$ Really, they had nothing more than a rough sketch. On one side of the line fell "private" things, such as "private life, habits, acts and relations of an individual," and on the other fell "public" things such as "fitness for a public office." 34 Beyond that, as Warren and Brandeis suggested, any rule establishing liability for invasion of privacy had to have "elasticity" to it. ${ }^{35}$

Seventy years later, when William L. Prosser wrote Privacy, journalism had changed dramatically. ${ }^{36}$ It was no longer driven primarily by bias and shock value. Instead, journalism had been professionalized, and objectivity and independence were institutional values. ${ }^{37}$ Public perception of journalists had correspondingly improved. ${ }^{38}$ Perhaps it is unsurprising then that Prosser's conception of newsworthiness was far broader than that of Warren and Brandeis. ${ }^{39}$ Prosser defined news as "includ[ing] all events and items of information which are out of the ordinary humdrum routine, and which have 'that indefinable quality of

29. Id. at 196.

30. Id. To be fair, The Right to Privacy, was written at a time when newspapers were often propaganda machines sponsored by political parties and sensational news coverage was common. See Michael Schudson, The Sociology of News 72-73 (2003) (noting that "[j]ournalism was only thinly differentiated from politics" and papers developed "crowd-pleasing" mechanisms like "sensational news coverage") [hereinafter Schudson, The Sociology of News].

31. See Warren \& Brandeis, supra note 21, at 214.

32. Id. at 215 .

33. Id. at $215-16$.

34. Id. at 216 .

35. Id. at 215 .

36. See Schudson, The Sociology of News, supra note 30, at 74-81; Prosser, supra note 22, at 386-88; Neil M. Richards, The Limits of Tort Privacy, 9 J. Telecomm. \& High Tech. L. 357, 364 (2011).

37. See Schudson, The Sociology of News, supra note 30, at 78-81.

38. See id. at 79; see also Michael Schudson, Why Democracies Need an Unlovable Press 35 (2008) ("The professionalization of American journalism reached a high point in the 1950s and 1960s — what media scholar Daniel Hallin has called its era of 'high modernism."”).

39. This also may have been due to Prosser's skepticism of the privacy torts. See Richards \& Solove, supra note 15 , at 1890 . 
information which arouses public attention." "40 This definition was so sweeping, and so implicitly trusting of the press, that it included virtually anything new.

Although this definition is certainly easier to apply than that of Warren and Brandeis (virtually everything falls within it), it still seems far from finished. To call news "indefinable" and in the eye of the beholder fails in the same way Justice Potter Stewart's definition of "hard-core pornography" did. ${ }^{41}$ Prosser went on, however, to narrow his definition in an important way. News was not, he said, just what any observer believed it to be. News was what a journalist believed it to be. He wrote: "To a very great extent the press, with its experience or instinct as to what its readers will want, has succeeded in making its own definition of news. A glance at any morning newspaper will sufficiently indicate the content of the term." 42

While Prosser's Privacy was influential, what secured the importance of this definition going forward (and, correspondingly, the media's own role in shaping the definition) was its incorporation seven years later in the Restatement (Second) of Torts, for which Prosser was the Reporter. ${ }^{43}$ In its comments, the Restatement defines "news," saying: "Included within the scope of legitimate public concern are matters of the kind customarily regarded as 'news.' To a considerable extent, in accordance with the mores of the community, the publishers and broadcasters have themselves defined the term, as a glance at any morning paper will confirm." ${ }^{44}$ Now, according to the most influential treatise on the subject, newsworthiness was what the press said it was.

\section{B. NEWSWORTHINESS AND THE COURTS' DEFERENCE TO THE EDITORIAL PROCESS}

As academics were envisioning and then describing the state of tort law, legislatures and courts were developing it. During the first half of the twentieth century numerous jurisdictions adopted right of privacy statutes, and courts crafted a common law of privacy. It was inevitable that these courts, including the Supreme Court, would confront the collision of privacy and First Amendment rights, and the courts have addressed this tension several times since the 1960 s. ${ }^{45}$ In these cases, time after time, courts have come down heavily on the side of speech. ${ }^{46}$ And in cases involving the media, courts have not just abstractly favored speech. Rather, they have signaled deference to the purveyors of that speech: the Fourth Estate. ${ }^{47}$ By and large, at least in their published

\footnotetext{
40. Prosser, supra note 22, at 412 (citation omitted).

41. See Jacobellis v. Ohio, 378 U.S. 184, 197 (1964) (Stewart, J., concurring) ("I know it when I see it ....").

42. Prosser, supra note 22, at 412.

43. See Richards \& Solove, supra note 15 , at 1890.

44. Restatement (SECond) of Torts at $§ 652 \mathrm{D} \mathrm{cmt}$. g (Am. Law Inst. 1977).

45. See, e.g., Bartnicki v. Vopper, 532 U.S. 514, 518, 528-29 (2001); Cox Broad. Corp. v. Cohn, 420 U.S. 469, 487-90 (1975).

46. See, e.g., Bartnicki, 532 U.S. at 534; Cox, 420 U.S. at 496.

47. See, e.g., Miami Herald Publ'g Co. v. Tornillo, 418 U.S. 241, 258 (1974).
} 
opinions, judges view the press as an institution with gravitas-a Fourth Estate in its purest sense, another branch of a functioning democratic government. Courts have indicated that they view the press as having well-developed institutional processes (seeing it as expert in discerning what news is), and judges have deemed those processes, namely editorial discretion, worthy of deference. ${ }^{48}$ Courts have, again and again, looked to the press itself to define newsworthiness. ${ }^{49}$

Any number of cases from the 1960s and 1970s could demonstrate the deference the Supreme Court has historically granted to the press. ${ }^{50}$ This was the era when New York Times Co. v. Sullivan ${ }^{51}$ and New York Times Co. v. United States ${ }^{52}$ (the "Pentagon Papers Case") were decided. ${ }^{53}$ Regarding privacy law specifically, Time, Inc. v. Hill provides a good example of the willingness of the Court to trust the media and defer to its democratic role. ${ }^{54} \mathrm{In}$ that case, the Court weighed the privacy of a family who had been taken hostage by escaped convicts against the right of Life Magazine to publish a story that portrayed (falsely, according to plaintiff) the hostage situation. ${ }^{55}$ In coming down on the side of the First Amendment, the Court invoked the Press Clause specifically when it wrote: "Exposure of the self to others in varying degrees is a concomitant of life in a civilized community. The risk of this exposure is an essential incident of life in a society which places a primary

48. See id.

49. See, e.g., Heath v. Playboy Enters., 732 F. Supp. 1145, 1149 n.9 (S.D. Fla. 1990) ("Moreover, the judgment of what is newsworthy is primarily a function of the publisher, not the courts.").

50. See, e.g., Smith v. Daily Mail Publ'g Co., 443 U.S. 97, 104-06 (1979) (finding the press had the right to publish the name of juvenile offenders); Landmark Commc'ns, Inc. v. Virginia, 435 U.S. 829, 839-42 (1978) (finding it was unconstitutional to punish a newspaper for violating a law that prevented disclosure of certain government proceedings); Okla. Publ'g Co. v. Dist. Ct., 430 U.S. 308, 311 (1977) (finding it was unconstitutional to bar the media from publishing material "publicly revealed" in a juvenile court proceeding); Neb. Press Ass'n v. Stuart, 427 U.S. 539, 541, 569 (1976) (holding an order preventing press from publishing information related to a pending criminal trial was unconstitutional); Time, Inc. v. Pape, 401 U.S. 279, 292 (1971) (finding a magazine's "error of judgment" did not constitute actual malice in publishing information about a public official).

51. 376 U.S. 254 (1964).

52. 403 U.S. 713 (1971).

53. In New York Times v. United States, the Court refused to enjoin newspapers from publishing secret government documents about the Vietnam War. Id. at 714. The per curiam opinion in the case was only a few paragraphs long, $i d$., but the concurring opinion written by Justice Black and joined by Justice Douglas stated, "[b]oth the history and language of the First Amendment support the view that the press must be left free to publish news, whatever the source, without censorship, injunctions, or prior restraints." Id. at 717 (Black, J., concurring). Further describing the hands-off approach that government should exercise toward the press, Justice Black wrote:

In the First Amendment the Founding Fathers gave the free press the protection it must have to fulfill its essential role in our democracy. The press was to serve the governed, not the governors. The Government's power to censor the press was abolished so that the press would remain forever free to censure the Government.

Id.

54. 385 U.S. 374 (1967).

55. Id. at $378-79$. 
value on freedom of speech and of press." ${ }^{56}$ The Court also signaled that the scope of newsworthiness is broad, writing, "[o]ne need only pick up any newspaper or magazine to comprehend the vast range of published matter which exposes persons to public view, both private citizens and public officials." ${ }^{57}$

Similarly, and a bit more recently, despite the acute privacy interests at stake, the Court held in favor of media defendants in Cox Broadcasting Corp. v. $\mathrm{Cohn}^{58}$ and Florida Star v. B.J.F. ${ }^{59}$ In Cox, the father of a rape-murder victim sued for invasion of his right to privacy after the media plaintiff identified his daughter during its coverage of the trial of the alleged rapists. ${ }^{60}$ In Florida Star, a rape victim sued a newspaper for publishing her name in violation of its own internal policy against publishing the names of sexual offense victims. ${ }^{61}$ In both cases, the Court spoke of the need to trust the press. In Cox, it wrote that "reliance must rest upon the judgment of those who decide what to publish or broadcast." $"$ This sentiment was so important that fourteen years later in Florida Star, the Court repeated it verbatim. ${ }^{63}$ These statements were indicative of the Court's belief that the press was to be trusted and allowed to do its important job.

In the broad range of tort cases against the press, the Court has consistently reasoned that it is deferring not simply to the press as an institution and the role it plays in democracy, but to the editorial process that it exercises. The suggestion is that judges feel comfortable deferring to the press because of the press's expertise in determining newsworthiness. Take, for example, Miami Herald Publishing Co. v. Tornillo. ${ }^{64}$ In siding with the press in that case, Justice Burger wrote: "The choice of material to go into a newspaper, and the decisions made as to limitations on the size and content of the paper, and treatment of public issues and public officials-whether fair or unfair-constitute the exercise of editorial control and judgment." ${ }^{25}$ Warning of the dangers of interfering with or second-guessing journalists' exercise of editorial judgment, he continued, "[i]t has yet to be demonstrated how governmental regulation of this crucial process can be exercised consistent with First Amendment guarantees of a free press as they have evolved to this time." $" 66$

\footnotetext{
56. Id. at 388 .

57. Id.

58. 420 U.S. 469 (1975).

59. 491 U.S. 524 (1989).

60. Cox, 420 U.S. at $471-75$.

61. Florida Star, 491 U.S. at 527-29; see Peter B. Edelman, Free Press v. Privacy: Haunted by the Ghost of Justice Black, 68 TEx. L. Rev. 1195, 1222-23 (1990) (noting that the plaintiff's case in Florida Star "could hardly have been more compelling").

62. Cox, 420 U.S. at 496.

63. Florida Star, 491 U.S. at 538.

64. 418 U.S. 241 (1974).

65. Id. at 258 .

66. Id.
} 
In fact, the Supreme Court has indicated the press is in the best position to determine what qualifies as news. In Columbia Broadcast System, Inc. $v$. Democratic National Committee, the Court stated: "Nor can we accept the Court of Appeals' view that every potential speaker is 'the best judge' of what the listening public ought to hear or indeed the best judge of the merits of his or her views. All journalistic tradition and experience is to the contrary."67 Deferring to the press's essential, if imperfect work, the Court continued: "For better or worse, editing is what editors are for; and editing is selection and choice of material." ${ }^{68}$ Consequently, it determined the "journalistic judgment of priorities and newsworthiness" 69 needed to be protected. ${ }^{70}$ In other words, no one is better than the press at determining what qualifies as newsworthy. ${ }^{71}$

In invasion of privacy cases, lower courts have generally adopted the same stance and, when they defer to the press, have shown particular deference to editorial judgment and the editorial decision-making process. For example, in Gilbert v. Medical Economics Co., when an anesthesiologist sued a magazine over an article linking her psychiatric problems to malpractice, the Tenth Circuit affirmed summary judgment for the magazine finding the topic newsworthy. ${ }^{72}$ The Tenth Circuit endorsed the district court's view that to find otherwise "would amount to 'editorial second-guessing' rather than legal analysis."73 Similarly, in finding that reporting the identity of a rape victim was newsworthy, the Fifth Circuit in Ross v. Midwest Communications, Inc. wrote that "[e]xuberant judicial blue-pencilling after-the-fact would blunt the quills of even the most honorable journalists."74 Judges, the court wrote, "must resist the temptation to edit journalists aggressively.",75 It added: "Reporters must have some freedom to respond to journalistic exigencies without fear that even a slight, and understandable, mistake will subject them to liability." ${ }^{, 76}$ Likewise, in Finger v. Omni Publications International, Ltd., New York's highest court affirmed a motion to dismiss a claim brought by a family of eight — whose photograph had been featured in conjunction with an article about caffeine-aided fertilizationwriting: "[Q]uestions of 'newsworthiness' are better left to reasonable editorial judgment and discretion." 77

67. 412 U.S. 94, 124 (1973).

68. Id.

69. Id. at 118 .

70. See id. at 131-32.

71. See Miami Herald Publ'g Co. v. Tornillo, 418 U.S. 241, 258 (1974).

72. 665 F.2d 305, 306-07, 310 (10th Cir. 1981) (relying on language from the trial court's opinion).

73. Id. at 307.

74. 870 F.2d 271, 275 (5th Cir. 1989).

75. Id.

76. $I d$.

77. 566 N.E.2d 141, 144 (N.Y. 1990). See also Gaeta v. Home Box Office, 645 N.Y.S.2d 707, 709, 713 (N.Y. Civ. Ct. 1996) (quoting this same language and upholding summary judgment in favor of a cable network sued by a woman who had been shown reacting to a display of public nudity). 
Numerous other decisions contain similar language. The Ninth Circuit has warned against "unduly limiting the breathing space needed by the press for the exercise of effective editorial judgment." 78 The Second Circuit has said that "[a] court cannot substitute its judgment for that of the press by requiring the press to present an article or broadcast in what the court believes is a balanced manner."79 A federal court in Florida, finding for Playboy magazine, wrote that "issues of good taste and editorial judgment are for the media and not for the courts." ${ }^{80}$ And the California Supreme Court has written that "[i]n general, it is not for a court or jury to say how a particular story is best covered." $\$ 1$

And so, implicit in these decisions is the suggestion that it is the press and its editorial process that transforms what may be merely news or of public interest into what is newsworthy or of legitimate public interest. In other words, someone must determine what is worthy and legitimate and, as the decisions described show, courts have largely left the role to the press. The refusal to blue-pencil journalists indicates judges believe journalists are engaging in a decision-making process worthy of judicial deference. These opinions again and again say journalists (not the courts) are in the best position to determine what is of legitimate public interest. They channel the Restatement's position that journalists "have themselves defined" what it means to be newsworthy "as a glance at any morning paper will confirm." 82

\section{The Role of Algorithms in Defining Newsworthiness}

Each year the Pew Research Center issues a report entitled the State of the News Media. ${ }^{83}$ The 2005 report begins by describing a mockumentary, circulat-

78. Virgil v. Time, Inc., 527 F.2d 1122, 1129 (9th Cir. 1975).

79. Machleder v. Diaz, 801 F.2d 46, 55 (2d Cir. 1986).

80. Heath v. Playboy Enters., Inc., 732 F. Supp. 1145, 1151 (S.D. Fla. 1990).

81. Shulman v. Grp. W Prods., Inc., 955 P.2d 469, 485 (Cal. 1998); see also Cinel v. Connick, 15 F.3d 1338, 1346 (5th Cir. 1994) ("[W]e are not prepared to make editorial decisions for the media regarding information directly related to matters of public concern.”); Star-Telegram, Inc. v. Doe, 915 S.W.2d 471, 477 (Tex. 1995) ("Journalists should be able to respond to journalistic exigencies without fear of liability imposed by aggressive judicial editing." (internal quotations and citations omitted)). To be sure, recently there has been one very public and significant exception to this deference-albeit in a decision rendered by a jury rather than a judge. In 2016, a Florida jury awarded former professional wrestler Hulk Hogan \$140 million after Gawker.com published a sex tape involving him. See Greg Toppo, Jury Awards Hulk Hogan \$25 Million In Punitive Damages for Posting Sex Tape, USA TodAY (Mar. 21, 2016), http://www.usatoday.com/story/news/2016/03/21/jury-awards-hulk-hogan-25-millionpunitive-damages-posting-sex-tape/82093604/ [https://perma.cc/8E2J-29XY]. The verdict could be a sign of a backlash against the press's First Amendment rights. This backlash is the subject of Amy Gajda's book, The First Amendment Bubble, in which she discusses a "nascent trend of favoring privacy over press rights." See Amy Gajda, The First Amendment Bubble 55 (2015) (citation omitted). Yet, there continue to be disclosure of private facts cases deferring to the press. See, e.g., Phillips v. Consol. Publ'g Co., No. CV213-069, 2015 WL 5821501, at*14-17 (S.D. Ga. Sept. 14, 2015).

82. Restatement (Second) of Torts at $§ 652$ D cmt. g (Am. Law Inst. 1977).

83. See Previous State of the News Media Reports, Pew Research Ctr.: Journalism \& Media, http://www.journalism.org/2017/06/01/archived-state-of-the-news-media-reports/ [https://perma.cc/ Q93F-S3BG] (providing links to State of the Media reports from 2004 through 2016). 
ing at the time among journalists, about the future of news. ${ }^{84}$ Set in 2014 , the mockumentary tells the apocalyptic story of a future where The New York Times has become a newsletter for the "elite and elderly" and a company called "Googlezon" provides each consumer with a "one-of-a-kind news product each day based on his or her personal data." 85 The film concludes with the lament: "It didn't have to be this way." 86 Commenting on this ending, the Pew report says: "And it probably won't be." 87

The hesitancy was prescient. While today there is no Googlezon, other platforms ably play the part and do just what the fictional behemoth did: provide consumers with a personalized news product. ${ }^{88}$ In little more than a decade there has been a seismic shift in the way that news is produced and consumed. ${ }^{89}$ The democracy-enhancing values that have traditionally undergirded the production of news - truth, transparency, and accountability - are giving way to the consumer and profit-driven values that motivate platforms.

\section{A. THE NEW PURVEYORS OF NEWS}

Today, very few of us read the morning paper that, according to the Restatement, would tell us what is newsworthy. ${ }^{90}$ Instead, we are glued to our phones. ${ }^{91}$ Our phones have become the means for messaging friends, buying shoes, mapping our driving route, and finding a cup of coffee; they are also our portals to news. ${ }^{92}$ Platforms like Facebook and Twitter are increasingly where we go to find news about our neighborhoods, nation, and world. ${ }^{93}$ While many of us still watch cable news, local television news, and listen to broadcast news, digital

84. Project for Excellence in Journalism, Overview-Intro, The State of the News Media: 2005, Pew ResEarch CTR. (2005), http://www.stateofthemedia.org/2005/overview/ [https://perma.cc/3G2M-B W46]; Robin Sloan \& Matt Thompson, EPIC 2014, RobIN SLOAN, https://www.robinsloan.com/epic/ [https://perma.cc/D9BC-PJPC] (providing a link to the mockumentary).

85. See Project for Excellence in Journalism, supra note 84.

86. See id. The version of the film available at the site to which the Pew report links no longer includes this language. See Sloan \& Thompson, supra note 84.

87. See Project for Excellence in Journalism, supra note 84.

88. See Ravi Somaiya, How Facebook Is Changing the Way Its Users Consume Journalism, N.Y. TimEs, (Oct. 26, 2014), http://www.nytimes.com/2014/10/27/business/media/how-facebook-is-changingthe-way-its-users-consume-journalism.html?_r=0 [https://nyti.ms/2jObE2x] (quoting Facebook's Mark Marra as saying “[w]e don't want to have editorial judgment over the content that's in your feed. You've made your friends, you've connected to the pages that you want to connect to and you're the best decider for the things you care about").

89. See Emily Bell \& Taylor Owen, The Platform Press: How Silicon Valley Reengineered JouRnALISM 9 (2017), http://towcenter.org/wp-content/uploads/2017/04/The_Platform_Press_Tow_Report_ 2017.pdf [https://perma.cc/3N99-TYU3] (describing the "rapid takeover of traditional publishers' roles by companies including Facebook, Snapchat, Google, and Twitter that shows no sign of slowing").

90. See Mitchell, ET Al., supra note 5, at 4 (noting just twenty percent of Americans get their news from newspapers, down from twenty-seven percent in 2013).

91. See Pompeo, supra note 4 (noting that "everyone's reading the news on their phones").

92. See Bell, supra note 11 ("Social media hasn't just swallowed journalism, it has swallowed everything. It has swallowed political campaigns, banking systems, personal histories, the leisure industry, retail, even government and security. The phone in our pocket is our portal to the world.").

93. See Herbst, supra note 7. 
media is transforming legacy media. ${ }^{94}$

Each week, 600 million people see a news story on Facebook. ${ }^{95}$ And according to a recent study by the Pew Research Center, about four out of ten adults in the United States get news on Facebook and about one out of ten get it on each of Twitter and YouTube. ${ }^{96}$ The numbers are growing, and the growth is likely to continue given that nearly half of readers below the age of thirty-five consider Facebook and Twitter to be either an important or the most important way that they get news. ${ }^{97}$

These companies' CEOs are unabashed in expressing their ambition that their platforms will be the key place we find news in the future. Facebook's Mark Zuckerberg hopes that his company will provide the "primary news experience people have." 98 Similarly, Twitter's CEO Jack Dorsey recently told Vanity Fair, "I want people to wake up every day and the first thing they check is Twitter in order to see what's happening in the world."99 The companies' news ambitions are evident even in the way they label themselves and their products. Facebook

94. See Pew Research Ctr., State of the News Media: 2016, at 5-6 (2016), http://assets.pewresearch. org/wp-content/uploads/sites/13/2016/06/30143308/state-of-the-news-media-report-2016-final.pdf [https:// perma.cc/4B4D-V4NT]. The picture of what is happening to the news industry is complex. Although newspapers are losing readership rapidly, cable news and network news are remaining steady or growing. See id. at 5, 22, 37. Radio listenership is also strong, if online radio and podcasts are considered. See id. at 61, 69. Regardless, all news media is being transformed by the move to digital. See id. at 6 ("It has been evident for several years that the financial realities of the web are not friendly to news entities, whether legacy or digital only.").

95. Julia Greenberg, Facebook has Seized the Media, and That's Bad News for Everyone But Facebook, WIRED (Apr. 13, 2016, 3:04 PM), https://www.wired.com/2016/04/facebook-seized-mediathats-bad-news-everyone-facebook/ [https://perma.cc/P8PK-PAXQ].

96. Jeffrey Gottrried \& Elisa Shearer, Pew Research Ctr., News Use Across Social Media PlATFORMs 2016, at 4 (2016), http://www.journalism.org/files/2016/05/PJ_2016.05.26_social-media-andnews_FINAL-1.pdf [https://perma.cc/6SYD-26LX]. Of those who get their news on a social media site, sixty-four percent of them get news on just one site. See id. at 5. That site is most commonly Facebook. See id. Yet, those who get their news on social media have not completely forsaken other sources. See $i d$. at 8. For example, thirty-nine percent of Facebook users also get news from local television. See id.

97. Pew Research Ctr., The Evolving Role of News on Twitter and Facebook 13 (2015), http://www.journalism.org/files/2015/07/Twitter-and-News-Survey-Report-FINAL2.pdf [https://perma. cc/KGX9-4YRD]; see also GotTFRIED \& SHEARER, supra note 96, at 9 (showing that the percentage of Facebook users who get news on the site rose from forty-seven to sixty-six percent between 2013 and 2016, for Twitter from fifty-two to fifty-nine percent and for Instagram from thirteen to twenty-three percent).

98. Michael Nunez, Want to Know What Facebook Really Thinks of Journalists? Here's What Happened When It Hired Some, Gizmodo (May 3, 2016, 1:09 PM), http://gizmodo.com/want-to-knowwhat-facebook-really-thinks-of-journalists-1773916117 [https://perma.cc/3NB7-5LBB]; see also Eugene Kim, Mark Zuckerberg Wants to Build the 'Perfect Personalized Newspaper' for Every Person in the World, Business InSIDER (Nov. 6, 2014, 8:51 PM), http://www.businessinsider.com/mark-zuckerbergwants-to-build-a-perfect-personalized-newspaper-2014-11 [https://perma.cc/A34A-XGHP] (quoting Zuckerberg as saying that the company's goal is "to build the perfect personalized newspaper for every person in the world").

99. Nick Bilton, Twitter is Betting Everything on Jack Dorsey. Will It Work?, VANITy FAIR: Hive (Summer 2016), http://www.vanityfair.com/news/2016/06/twitter-is-betting-everything-on-jack-dorsey [https://perma.cc/Q5ZK-WFC8]. 
has a "News Feed," and Twitter classifies itself as a "news" app. ${ }^{100}$

Yet, at the same time, Facebook in particular has adamantly resisted taking on the mantle of the media. Rather, it has worked hard to present itself as little more than a conduit for its users' interests and desires. ${ }^{101}$ For example, in the immediate aftermath of the election of Donald Trump as president, Zuckerberg scoffed at the notion that Facebook had influenced the outcome, calling it a "pretty crazy idea." 102 He also wrote: "News and media are not the primary things people do on Facebook, so I find it odd when people insist we call ourselves a news or media company." 103

In certain ways, executives like Zuckerberg are correct that platforms are not media companies. Their products differ in fundamental ways from the go-to news sources of just a few years ago. At least for now, platforms are merely publishers and distributors of news. ${ }^{104}$ This contrasts with legacy news organizations (those pre-dating the Internet) that are generally producers and publishers and distributors of news. ${ }^{105}$ For example, when a reader picks up The Washing-

100. See Sarah Perez, Twitter Aims to Boost Its Visibility By Switching From 'Social Networking' to 'News' on the App Store, TECHCRUNCH (Apr. 28, 2016), https://techcrunch.com/2016/04/28/twitter-aimsto-boost-its-visibility-by-switching-from-social-networking-to-news-on-the-app-store/ [https://perma.cc/ L74N-VYTC].

101. John Herrman, What We've Learned About the Media Industry During This Election, N.Y. TimES (Nov. 8, 2016), https://www.nytimes.com/2016/11/09/business/media/what-weve-learned-aboutthe-media-industry-during-this-election.html [https://nyti.ms/2kGWsVU] (noting at a conference during the summer of 2016, Mark Zuckerberg said, "[w]e are a tech company, not a media company"). It could be argued that Facebook has, at least by association, been hostile to the media. Its board member Peter Thiel helped fund litigation that drove Gawker to bankruptcy. See Matt Rosoff, Why Facebook Is So Terrifying to Media Companies, Business Insider (June 29, 2016, 8:05 PM), http://www. businessinsider.com/facebook-is-a-media-company-not-a-journalism-company-2016-6 [https://perma.cc/ B6SX-DS83].

102. See Mike Isaac, Facebook, in Cross Hairs After Election, Is Said to Question Its Influence, N.Y. TімES (Nov. 12, 2016), http://www.nytimes.com/2016/11/14/technology/facebook-is-said-to-question-itsinfluence-in-election.html [https://nyti.ms/2kpxYfV] (internal quotations omitted); see also Barbara Ortutay, Mark Zuckerberg: That Facebook Influenced Election Is 'Crazy,' WASH. Times (Nov. 11, 2016), http://www.washingtontimes.com/news/2016/nov/11/zuckerberg-that-facebook-influenced-election-is-cr/ [https://perma.cc/X6YM-JVGU].

103. See Jeff John Roberts, Why Facebook Won't Admit It's a Media Company, Fortune (Nov. 14, 2016), http://fortune.com/2016/11/14/facebook-zuckerberg-media/ [https://perma.cc/WVA9-JKJ7]. Twitter has been less adamant about refusing to be called a media company and, in fact, Dorsey has called it the "People's News Network." See Christopher Mims, Why Twitter Is Actually a Media Company; Twitter Increasingly Is the Place Where Content Is Born, WALL ST. J. (Oct. 16, 2016), http://www.wsj. com/articles/why-twitter-is-actually-a-media-company-1476642632 [https://perma.cc/QK78-EH9F].

104. There are some companies that buck this trend. For example, Yahoo has a newsroom and numerous journalists, including Katie Couric, on its payroll. See Sarah Ellison, Marissa Mayer vs. "Kim Kardashian's Ass”: What Sunk Yahoo's Media Ambitions?, VANity FAIR: Hive (Apr. 4, 2016), http://www. vanityfair.com/news/2016/04/marissa-mayer-vs-kim-kardashians-ass-what-sunk-yahoos-mediaambitions [https://perma.cc/9JTU-SLB8]. Yet, the media side of its business is now being "reined in" as the company "approaches a potential sale." Id.

105. See Bell \& Owen, supra note 89, at 23 (describing how legacy news organizations and others are ceding the role of distributor to platforms); Jeffrey F. Rayport \& John Sviokla, Managing in the Marketspace, HaRv. Bus. REv. (Nov.-Dec. 1994), https://hbr.org/1994/11/managing-in-the-marketspace [https://perma.cc/9GJJ-YZPP] (describing the components of a newspaper as not only including content but infrastructure, such as a printing plant and trucks). 
ton Post or even views its website, she reads content written by reporters and editors employed by The Washington Post and published in a product that is printed and distributed by The Washington Post. In contrast, when the same reader opens the Apple News app, for example, she is using a platform that has trawled the Internet for articles, video, and other content and chosen a handful of them based on her preferences. ${ }^{106}$ Apple News curates but does not create content. ${ }^{107}$

Disaggregation - the way in which platforms pull and repackage content from a variety of different providers - is not unique to media. Technology has eliminated the middlemen in countless industries. ${ }^{108}$ The effect on the media, however, has been particularly dramatic. There has been a "radical diffusion of the various particles of how we used to understand the operation of the press," says Kate Crawford, a principal researcher at Microsoft Research and a visiting professor at MIT's Center for Civil Media. 109 "This idea that the press was held in the venerable houses of The New York Times, The Washington Post, the Financial Times, The Guardian has really changed."110 Today, says Crawford, "[w]e see players like Snapchat, Facebook, Twitter, Instagram, playing extraordinarily powerful new roles in the dissemination and understanding of information in the world." 111

There are at least two reasons that the control these companies exercise is so extraordinary. One is audience. Given the vast number of people using Facebook - at least 1.5 billion worldwide - the platform has "immense power."112 The other is advertising. While many advertisers traditionally relied on newspapers, television, and radio to reach certain audiences (primarily geographicallybased ones), they now can more effectively pinpoint consumers using the

106. See Julia Greenberg, Apple Finally Kills Newsstand to Make Way for Apple News, WIRED (Sept. 16, 2015, 7:00 AM), https://www.wired.com/2015/09/apple-finally-kills-newsstand-make-way-applenews/ [https://perma.cc/3ST9-QNSD].

107. See id.

108. See Paul Lillrank, The Evolution of Organizational Structures in a Networked Society: The Case of Finland, in Digital Economy and Social Design 168-69 (Osama Sudoh ed., 2005) (noting a key component of the "dot.com boom" was "that traditional demand-supply chains could be disaggregated and reconstructed, eliminating unnecessary middlemen and overcoming information-based constraints"); Rayport \& Sviokla, supra note 105 (describing how technology has streamlined transactions in numerous industries).

109. Columbia Journalism School, Journalism + Silicon Valley Conference-Full Day-Tow Center Nov. 12, 2015, YouTube (Nov. 13, 2015), https://www.youtube.com/watch?v=0Qftw6VkDKQ (starting at 52:30). Of course, the Internet is changing many industries in similar ways. The first decade of the twenty-first century has been called the "disintermediation decade" for the way that the Internet has eliminated the middleman in "every business, art, and profession that aggregates and repackages." Eli Pariser, The Filter Bubble 59 (2011) (quoting Jon Pareles and Dave Winer) (internal quotations omitted).

110. Columbia Journalism School, supra note 109 (starting at 52:30).

111. Id.

112. Greenberg, supra note 95. 
Internet. ${ }^{113}$ Why should Honda, for example, spend its advertising dollars attempting to reach all the Miami Herald's readers when it can target its ads to Internet users known to be searching for a new car? ${ }^{114}$

In search of the audience and revenue that once came to them, legacy news organizations are now reliant on Facebook and its brethren. ${ }^{115}$ And now that platforms control the information pathways, they can control content. Facebook, for one, "dictates how resources are spent and what stories are told," says Julia Greenberg in Wired magazine. ${ }^{116}$ "Facebook is setting the rules, and news organizations are following." "117 Every tweak to Facebook's algorithm sets off a new round of handwringing, soul searching, and strategizing by traditional media companies. ${ }^{118}$ As the shift to digital and social media news sources continues, this phenomenon in newsrooms will only accelerate.

Perhaps the most impactful rule that Facebook and other platforms have set is this: the content shown to a user is the content relevant to them. According to the platforms, relevant content is the content a user wants to consume. ${ }^{119}$ Platforms spend an enormous amount of effort gathering information about

113. Bill Kovach \& Tom Rosenstiel, Blur: How to Know What's True in the Age of Information OVERLOAD 7 (2010).

114. PARISER, supra note 109, at 49 ("Instead of taking out expensive advertisements in the New York Times, it was now possible to track that elite cosmopolitan readership using data acquired from [data firms]. This was, to say the least, a game changer in the business of news. Advertisers no longer needed to pay the New York Times to reach Times readers: they could target them wherever they went online. The era where you had to develop premium content to get premium audiences, in other words, was coming to a close.").

115. See Bell, supra note 11 ("Publishers are reporting that [Facebook's] Instant Articles are giving them maybe three or four times the traffic they would expect. The temptation for publishers to go 'all in' on distributed platforms, and just start creating journalism and stories that work on the social Web, is getting stronger. I can imagine we will see news companies totally abandoning production capacity, technology capacity, and even advertising departments, and delegating it all to third-party platforms in an attempt to stay afloat. This is a high-risk strategy."). Facebook in particular "has become a crucial distribution platform for publishers. Facebook has the audience news organizations are trying to reach, so they have little choice but to chase it there." Greenberg, supra note 95.

116. Greenberg, supra note 95.

117. Id.

118. See Damon Beres, Facebook Just Gave the Finger to Millions of People Who Use It For News, HufFington Post (June 29, 2016), http://www.huffingtonpost.com/entry/facebook-news-feed-update_us_ 5773dac3e4b0eb90355cf524 [https://perma.cc/PE5A-CP3G] ("Facebook's algorithm tweaks always tend to send the media into a frenzy. And yes, that's partially because writers rely on Facebook to reach their audience and get paid."); Mike Isaac \& Sydney Ember, Facebook to Change News Feed to Focus on Friends and Family, N.Y. Times (June 29, 2016), http://www.nytimes.com/2016/06/30/technology/ facebook-to-change-news-feed-to-focus-on-friends-and-family.html [https://nyti.ms/298Vw7Z].

119. According to media scholar Tarleton Gillespie, an "algorithm approximates "relevance." See Gillespie, supra note 6, at 175 . He adds:

' $[R]$ elevant' is a fluid and loaded judgment, as open to interpretation as some of the evaluative terms media scholars have already unpacked, like 'newsworthy' or 'popular.' As there is no independent metric for what actually are the most relevant search results for any given query, engineers must decide what results look 'right' and tweak their algorithm to attain that result, or make changes based on evidence from their users, treating quick clicks and no follow-up searches as an approximation, not of relevance exactly, but of satisfaction.

Id. 
users and trying to discern from it what individual users want to read and see. According to Facebook executives, products like News Feed "are helping you find the things that you care about." ${ }^{120}$ Describing the operating premise of News Feed, one Facebook executive told The New York Times: "We think that of all the stuff you've connected yourself to, this is the stuff you'd be most interested in reading." 121

This commitment to relevance has often been at the direct expense of news. For example, in June 2016, in the midst of the presidential election, Facebook changed its algorithm to prioritize updates from friends and family over those posted by news outlets. ${ }^{122}$ In the same time period, it also fired the few human editors it employed-those who oversaw its "trending topics" section. ${ }^{123} \mathrm{~A}$ short time later, Facebook experienced a surge in "fake news"- "news articles that are intentionally and verifiably false" 124 - on the site. ${ }^{125}$

And so, in focusing on relevance to a single user, platforms have cast aside the importance of relevance to the general public or a community of readers, the very thing that has animated journalism. This schism between algorithmic and journalistic relevance is changing the concept of newsworthiness.

\section{B. THE "LIMINAL PRESS": ALGORITHMS AND THEIR CREATORS}

Underlying what appears on our screens when we open Facebook, Apple News, or Twitter is code. Code is used to construct a complex web of algorithms that work behind the scenes to determine what content we see on these sites. ${ }^{126}$ Put simply, these algorithms are problem-solving formulas. ${ }^{127}$ If the problem is determining what users want to read, algorithms solve that problem by processing a wealth of information about that user and making predictions based on it.

Here is a rough sketch of how it works with respect to Facebook: whenever you open the site, the algorithm examines all of the content recently posted to Facebook by your friends, those you follow, the groups you belong to, and the pages you have "liked." "It then assigns a relevancy score to each one of these

120. Somaiya, supra note 88 (quoting Greg Marra, a Facebook engineer).

121. Id.

122. Zeynep Tufekci, Mark Zuckerberg Is in Denial, N.Y. Times (Nov. 15, 2016), http://www.nytimes. com/2016/11/15/opinion/mark-zuckerberg-is-in-denial.html [https://nyti.ms/2eAFNRH].

123. $I d$.

124. Hunt Allcott \& Matthew Gentzkow, Social Media and Fake News in the 2016 Election, $31 \mathrm{~J}$. ECON. PERSPS. 211, 213 (2017), https://web.stanford.edu/gentzkow/research/fakenews.pdf [https://perma. cc/F2JH-KLWS].

125. Id. at 212; Bell \& Owen, supra note 89, at 15; see also Brian Stelter, The Plague of Fake News Is Getting Worse-Here's How to Protect Yourself, CNN MoneY (Nov. 1, 2016), http://money.cnn.com/ 2016/10/30/media/facebook-fake-news-plague/index.html [https://perma.cc/W5TZ-4FKJ] (noting that the problem of fake news goes beyond Facebook).

126. See Somaiya, supra note 88 .

127. See id.

128. See Oremus, supra note 6. 
posts. ${ }^{129}$ The post you see at the top of the feed has the highest relevancy score. $^{130}$

Determining relevancy score is a secretive process. Reports vary wildly as to the number of variables that Facebook's algorithm uses to determine relevancy, ranging from the hundreds to $100,000 .^{131}$ These variables include what is "trending" at any given time, meaning what is being clicked on and shared by other users. ${ }^{132}$ They also include what a user's friends are sharing. The variables account for what a reader has shown interest in previously. ${ }^{133}$ The algorithm may well know a user's purchasing history, sexual orientation, and political affiliation. $^{134}$

While it is easy to think of algorithms with their lines and lines of code as cold and objective (and technology companies often portray them this way), they have human creators. ${ }^{135}$ Computer engineers, designers, and coders build and manage these algorithms. The people behind the algorithm decide what variables to use and how to weigh them relative to one another. Their preferences are the algorithm's preferences. Their assumptions are the algorithm's assumptions. ${ }^{136}$ And, as has concerned many observers, their prejudices are the

129. See id.

130. See id.

131. See Martin Beck, Facebook's News Feed Algorithm: A Guide to Recent Changes, MARKETING LAND (Oct. 30, 2015, 12:05 PM), http://marketingland.com/21-news-feed-updates-that-have-changedhow-pages-use-facebook-126066 [https://perma.cc/SQ4S-FPD4] (indicating that as many as 100,000 variables are used); Luckerson, supra note 6 ("Facebook says it uses thousands of factors to determine what shows up in any individual user's feed."); Oremus, supra note 6 (responding to a question about how many variables the algorithm has, Facebook's director of engineering for News Feed said "[h]undreds."); Michael Patterson, Edgerank: A Guide to the Facebook News Feed Algorithm, Sprout Social (Jan. 26, 2015), http://sproutsocial.com/insights/facebook-news-feed-algorithm-guide/ [https:// perma.cc/VYT2-PF85] (noting as of 2013 the algorithm was based on more than 1,000 different factors). Note also that for simplicity, I use the singular "algorithm." Yet, platforms use numerous algorithms simultaneously. Oremus, supra note 6 ("Facebook's news feed algorithm, like Google's search algorithm or Netflix's recommendation algorithm, is really a sprawling complex of software made up of smaller algorithms.")

132. See Luckerson, supra note 6 (noting Facebook's "algorithm also assumes content that has attracted a lot of engagement has wide appeal and will place it in more people's feeds").

133. See id.

134. See Josh Halliday, Facebook Users Unwittingly Revealing Intimate Secrets, Study Finds, GuARDiAN (Mar. 11, 2013, 3:00 PM), https://www.theguardian.com/technology/2013/mar/11/facebookusers-reveal-intimate-secrets [https://perma.cc/74QA-LQ8G]; Jeremy B. Merrill, Liberal, Moderate, or Conservative? See How Facebook Labels You, N.Y. TIMES (Aug. 23, 2016), http://www.nytimes.com/ 2016/08/24/us/politics/facebook-ads-politics.html [https://nyti.ms/2jF48ag].

135. See Evgeny Morozov, Don't Be Evil, New Republic (July 13, 2011), https://newrepublic.com/ article/91916/google-schmidt-obama-gates-technocrats [https://perma.cc/V85X-4X5W] ("Google's spiritual deferral to 'algorithmic neutrality' betrays the company's growing unease with being the world's most important information gatekeeper. Its founders prefer to treat technology as an autonomous and fully objective force rather than spending sleepless nights worrying about inherent biases in how their systems - systems that have grown so complex that no Google engineer fully understands themoperate.").

136. See Chava Gourarie, Investigating the Algorithms that Govern Our Lives, Colum. JouRnalism REv. (Apr. 14, 2016), http://www.cjr.org/innovations/investigating_algorithms.php [https://perma.cc/ TLS8-EB45]. 
algorithm's prejudices. ${ }^{137}$

These engineers, coders, and designers are now, in a sense, playing the same role as the editors sitting around the table at the Page One meeting. They are a gauntlet that content needs to run through before getting to the reader. They set the parameters that determine what gets weeded out and what is swept in. They also decide the "play"- to use a newspaper term-any particular piece of content is going to get.

Engineers, coders, and designers have assumed a societal role so similar to journalists that media sociologists have dubbed them a "liminal press."138 Although these technology company employees "may not self-identify as journalists," say Kate Crawford and Mike Ananny, a professor at the University of Southern California's Annenberg School for Communication and Journalism, they "define the conditions under which news is created and circulated." 139

Yet, the way "news is created and circulated" in their hands is strikingly different than at a legacy news organization. In 2014, Crawford and Ananny interviewed designers, programmers, and entrepreneurs to get a sense of the "values that people were encoding" into products that distributed news. ${ }^{140}$ Speaking at a conference held by the Tow Center for Digital Journalism, Crawford said of their results: "There was this thing we used to understand as journalistic ethics .... It's interesting to realize that those principles are really very different to a lot of the Silicon Valley companies that are becoming major players in this space." "I41 In their interviews, Crawford said, "[b]y far and away, the biggest value was 'We just want users .... We just want to be the most popular app in the space.",142

In the study, Crawford and Ananny write that although some of their interviewees "talked about themselves in relation to press practices and tradition, many of them also distanced themselves from journalism altogether." ${ }^{143}$ For example, when a senior news app designer was asked about the journalistic ideals that motivated him and his colleagues, he said,

I don't think that the people in this space who are doing this are familiar with these ideas of journalism that you're talking about except in the most cursory

137. See Farhad Manjoo, Facebook's Bias Is Built-In, and Bears Watching, N.Y. TIMES (May 11, 2016), http://www.nytimes.com/2016/05/12/technology/facebooks-bias-is-built-in-and-bears-watching. html [https://nyti.ms/2kaPfsJ] (indicating that "most of the stories Facebook presents to you are selected by its algorithms [and that] those algorithms are as infused with bias as any other human editorial decision").

138. Mike Ananny \& Kate Crawford, A Liminal Press, 3 Digital Journalism 192, 194 (2014), http://www.tandfonline.com/doi/abs/10.1080/21670811.2014.922322 [https://perma.cc/8599-UUPJ].

139. Id. at 193.

140. Columbia Journalism School, supra note 109, at 53:30.

141. Id. at 53:14.

142. Id. at 54:10.

143. Ananny \& Crawford, supra note 138, at 199. 
way. And even there, I don't think that they believe they're important. I think essentially, zero. I think there are no ideals being pursued. ${ }^{144}$

In speaking at the conference, Crawford summarized that the attitude seemed to be "if somebody just wants to read news stories about marmots or the Kardashians, that's completely fine." ${ }^{145}$ This outlook stood in contrast, she suggested, from "traditional ideas about responsibility to audience." 146

Others have also documented that Silicon Valley's focus is relevancy and "engagement" (clicking on an item and spending time reading or watching it) rather than newsworthiness. In his book, The Filter Bubble, Eli Pariser recounts calling Google in 2011 to ask company officials what they thought of Google's "enormous curatorial power." company replied: "We're just trying to give people the most relevant information." ${ }^{148}$ And in an interview with The New York Times, the product manager for the News Feed ranking team at Facebook, Mark Marra, said "We don't want to have editorial judgment over the content that's in your feed. You've made your friends, you've connected to the pages that you want to connect to and you're the best decider for the things that you care about."149

Thus, the driving force behind the news we consume is, more and more, not a journalist, but a formula. And the engineers, designers, and entrepreneurs behind that formula have no desire to be a Fourth Estate. As Slate's senior technology writer Will Oremus has written, while "[m]edia organizations have historically defined what matters to their audience through their own editorial judgment," Facebook engineers "have taken pains to avoid putting their own editorial stamp on the news feed."150

\section{NEWS JUDGMENT AND THE FOURTH ESTATE: JOURNALISM'S PERSPECTIVE}

Historically, journalists have not been shy about touting the importance of their contribution to the social order. In 1929, Walter Lippmann, co-founder of the New Republic, wrote that the "task of selecting and ordering" the news from among the "incredible medley of fact, propaganda, rumor, suspicion, clues, hopes and fears" that reached the newsroom "is one of the truly sacred and priestly offices in a democracy." 151 Not to shortchange the ultimate product, he called the newspaper "the bible of democracy, the book out of which a people determines its conduct." ${ }^{152}$ This is undoubtedly a rosy vision of the media's

144. Id. at 200 .

145. Columbia Journalism School, supra note 109, at 54:35.

146. Id. at 54:25.

147. PARISER, supra note 109 , at 176.

148. Id.

149. Somaiya, supra note 88; see Oremus, supra note 6 (noting Marra's title at Facebook).

150. Oremus, supra note 6.

151. Walter Lippmann, Liberty and the News 47 (1920); see also Kovach \& Rosenstiel, supra note 113 , at 170 .

152. LipPManN, supra note 151 , at 47 ; see Kovach \& Rosenstiel, supra note 113 , at 170-71. 
societal role, but it is one that many journalists earnestly believe in and still aspire to fulfill. ${ }^{153}$ There is also a good bit of truth to it.

It is well established that journalism is a public good. ${ }^{154}$ In economic terms, journalism "is non-rivalrous (one person's consumption of the news does not preclude another person's consumption of the same news) and non-excludable (once the news producer supplies anyone, it cannot exclude anyone)."155 Journalism is also a public good in a more colloquial sense. Traditionally most news organizations have been driven by more than just profits. They have spent vast amounts of capital lobbying and litigating open records and First Amendment issues. ${ }^{156}$ They have also undertaken expensive public accountability and investigative reporting and have sometimes reaped financial rewards, including improvement of the brand. ${ }^{157}$ But more often the primary benefit has been nothing more than "the warm glow of altruism." ${ }^{158}$ As The New York Times technology reporter Farhad Manjoo has written: "In a newsroom, news isn't just what people want to see, and ideas worth promoting aren't just those that people click on. News is supposed to exist outside those desires; it's supposed to be an objective good." 159

Until recently, journalists have been relatively insulated from concerns about profitability. ${ }^{160}$ Although editors have considered what will sell papers, an entirely separate side of the newspaper (the business side headed by a publisher) has been devoted to that concern. That means the editorial side has been freed

153. See, e.g., Margaret Sullivan, Opinion, Who's a Journalist? A Question with Many Facets and One Sure Answer, N.Y. TIMEs (June 29, 2013, 10:00 AM), http://publiceditor.blogs.nytimes.com/2013/ 06/29/whos-a-journalist-a-question-with-many-facets-and-one-sure-answer [https://nyti.ms/2oTm2Z1].

154. See James T. Hamilton, What's the Incentive to Save Journalism?, in WILl THE LAST REPORTER Please Turn Out the Lights: The Collapse of Journalism and What Can Be Done to Fix It 277, 280 (Robert W. McChesney \& Victor Pickard eds., 2011); Fed. Trade Comm'n, Staff Discussion Draft: Potential Policy Recommendations to Support the Reinvention of Journalism 4 (2010), https://www. ftc.gov/sites/default/files/documents/public_events/how-will-journalism-survive-internet-age/newstaff-discussion.pdf [https://perma.cc/HE4Y-8L42] ("The news is a 'public good' in economic terms.").

155. Fed. Trade Comm'n, supra note 154, at 4.

156. See RonNell Andersen Jones, Litigation, Legislation, and Democracy in a Post-Newspaper America, 68 Wash. \& LeE L. Rev. 557, 559 (2011).

157. See Nate Silver, Do Pulitzers Help Newspapers Keep Readers?, FiveThiRTyEight (Apr. 15, 2014, 9:56 AM), https://fivethirtyeight.com/datalab/do-pulitzers-help-newspapers-keep-readers/ [https:// perma.cc/E5N7-Y72L] (finding a "very modest positive correlation" between winning Pulitzer Prizes and increased circulation).

158. See Hamilton, supra note 154, at 278.

159. Farhad Manjoo, Facebook, A News Giant That Would Rather Show Us Baby Pictures, N.Y. TimES (June 29, 2016), http://www.nytimes.com/2016/06/30/technology/facebook-a-news-giant-thatwould-rather-show-us-baby-pictures.html [https://nyti.ms/298Wlh0].

160. See Schudson, The Sociology of News, supra note 30, at 115-16 (describing the "wall of separation' between the business and editorial sides of news organizations" and noting that "journalists themselves are the first line of defense against commercialism" in the news business); Sarah Ellison, Can Anyone Save the New York Times from Itself?, VAnity FaIR: Hive (June 1, 2016), http://www. vanityfair.com/news/2016/05/new-york-times-leadership-succession [https://perma.cc/Q56S-3ETW] (quoting ousted New York Times executive editor Jill Abramson on changes to the newsroom: "Call me old-fashioned . . . but I wanted the newsroom to focus on journalism, not revenue generation."). 
up to aspire to loftier goals, for example, exercising First Amendment rights. ${ }^{161}$ As Lippmann did almost a century ago, many journalists speak reverently about the profession's role in promoting First Amendment ideals. They trumpet their role as facilitator of the marketplace of ideas and watchdog of government. ${ }^{162}$ Take, for example, a former public editor for The New York Times, Margaret Sullivan, who said: "A real journalist is one who understands, at a cellular level, and doesn't shy away from, the adversarial relationship between government and press - the very tension that America's founders had in mind with the First Amendment." 163

More fundamentally, according to media experts Bill Kovach and Tom Rosenstiel, journalists virtually uniformly see their role as a democracyenhancing one. They have written that journalism's mission can be distilled to a precept: "The primary purpose of journalism is to provide citizens with the information they need to be free and self-governing." ${ }^{164}$ This precept has "remained consistent and enduring" despite the rise in digital-only news organizations and the broadening of the definition of journalist to include bloggers and others. ${ }^{165}$ Kovach and Rosenstiel cite studies conducted by the Pew Research Center and developmental psychologists at Stanford, Harvard, and the University of Chicago that determined journalists shared "an adamant allegiance to a set of core standards that are striking in their commonality and in their linkage to the public information mission."166

Journalists are not merely being self-important. A litany of legal scholars and political theorists agree that the Fourth Estate's role is central to the promotion of democracy. For example, as Robert C. Post has argued, the media provides citizens the information they need to debate the many issues being acted upon by their government, and, in facilitating this "public sphere," they "preserve the democratic legitimacy of our government." 167

161. See Schudson, Why Democracies Need an Unlovable Press, supra note 38, at 45 ("A news organization is not the simple product of writers dedicated to the search for truth. It is an endlessly volatile marriage between professional ideals and commercial ones, between the claims of factuality and the claims of story-telling, between the ambitions of analysis and the aims of entertainment.").

162. See Timothy E. Cook, Freeing the Presses: An Introductory Essay, in FreeIng the Presses: The First AmEndment in Action 1, 3 (Timothy E. Cook ed., 2005) (describing these two roles for the Fourth Estate).

163. Sullivan, supra note 153.

164. Bill Kovach \& Tom Rosenstiel, The Elements of Journalism: What Newspeople Should Know and the Public Should Expect 17-45 (3d ed. 2014).

165. See id. at 16.

166. Id. at 20-21.

167. Robert C. Post, A Progressive Perspective on Freedom of Speech, in THE Constitution In 2020, at 179, 182 (Jack M. Balkin \& Reva B. Siegel eds., 2009); see also Schudson, Why Democracies NeEd an Unlovable Press, supra note 38, at 12 ("Where there is democracy . . . or where there are forces prepared to bring it about, journalism can provide a number of different services to help establish or sustain representative government."). In fact, Post relies on the work of Alvin Gouldner who argues that the "public" is a creation of news. See Robert C. Post, Constitutional Domains: Democracy, Community, Management 78 (1995) (“[T]he 'emergence of the mass media and of the 'public' are 
How does the Fourth Estate do this? Like all institutions, it has norms and conventions. ${ }^{168}$ As Paul Horwitz has written, "the 'old' press" is a "First Amendment institution" in that it "is identifiable and long established; it is a major part of the infrastructure of public discourse; it follows its own norms, practices, and self-regulatory standards; and it is fully (if imperfectly) capable of acting autonomously." ${ }^{69}$ Or, as Brazilian journalist Ricardo Gandour has put it: "Journalism is a method." 170 Evidence of that method can be found in the Society of Professional Journalists' Code of Ethics. It includes four basic precepts: "seek truth and report it," "minimize harm," "act independently," and "be accountable and transparent." ${ }^{171}$ Countless news organizations aspire to such principles, whether those principles exist in writing or are simply part of the institutional norms. ${ }^{172}$ At The Dallas Morning News, those principles are carved right onto the stone above the building's front doors. ${ }^{173}$ That engraving reads, in part: "Build the news upon the rock of truth and righteousness. Conduct it always upon the lines of fairness and integrity." 174

Journalists do care about relevance. In fact, they often think about their stories in terms of what they aim to provide to their audience. ${ }^{175}$ For example, according to Tom Rosenstiel, executive director of the American Press Institute: "Some pieces are explainers. Others are just for the record to note some incremental development. Some pieces help people solve problems. Others are

mutually constructive developments.' To restrict the news is therefore simultaneously to restrict the public." (footnote omitted)).

168. Schudson, Why Democracies Need an Unlovable Press, supra note 38, at 51 (describing the press as an "establishment institution" and noting that "reporters and editors operate according to a set of professional norms that are themselves constraints on expression").

169. See Paul Horwitz, First Amendment Institutions 146 (2013).

170. Ricardo Gandour, Study: Decline of Traditional Media Feeds Polarization, Colum. Journalism REv. (Sept. 19, 2016), http://www.cjr.org/analysis/media_polarization_journalism.php [https://perma.cc/ CBW2-JYRC].

171. Society of Professional Journalists, SPJ Code of Ethics (revised Sept. 6, 2014), http://www.spj. org/pdf/spj-code-of-ethics.pdf [https://perma.cc/FZ8C-8DD5]. The Code elaborates on these four precepts. For example, with respect to truth seeking, it discusses the importance of "a special obligation to serve as watchdogs over public affairs and government." Id. As for minimizing harm, the Code counsels journalists to, among other things, "[a]void pandering to lurid curiosity, even if others do." Id. It indicates the importance of remaining independent by "distinguish[ing] news from advertising and shun[ning] hybrids that blur the lines between the two," and it emphasizes the importance of transparency by recommending that reporters "[r]espond quickly to questions about accuracy, clarity and fairness" and "[a]cknowledge mistakes and correct them promptly and prominently." Id. As these precepts make clear, "in making news decisions, traditional journalists ... exercise ethics-related judgments." GAJDA, supra note 81, at 122.

172. See, e.g., NPR, NPR Ethics Handbook, http://ethics.npr.org/wp-content/uploads/2012/05/NPR-E thics-Handbook-5.2.2012-Final-Edition.pdf [https://perma.cc/83MZ-8J7K] (describing its "Guiding Principles," which include journalism that is "as accurate, fair and complete as possible").

173. Hare, supra note 4.

174. Id.

175. See Tom Rosenstiel, The Brookings Institution, Solving Journalism's Hidden Problem: TERRIBLE ANALYTICS 4 (2016), http://www.brookings.edu/research/papers/2016/02/19-journalism-terribleanalytics-rosenstiel [https://perma.cc/GSN9-Y9FN]. 
watchdog journalism." 176 Yet, as noted earlier, relevance is not the only consideration. As media law scholar Amy Gajda has written: "Deciding what news is fit to print ... is not only a matter of confirming a public appetite for it (web sites like BestGore.com ... confirm that there is a public appetite for almost anything), it requires an examination of countervailing values." 177 Similarly, media scholar Michael Schudson has described a newspaper as "a set of editors and reporters narrating a view of what they understand to be important events to their reader, strained through the peculiar conventions of journalistic culture." ${ }^{178}$ While Schudson says that editors and reporters take "popular expectations and tastes" into account, the newspaper shows those expectations and tastes "reflected and inflected through editorial judgment." 179 In other words, journalistic relevance isn't synonymous with audience desire.

Even the very word "news" demonstrates the way in which the Fourth Estate operates differently from an algorithm. It is not coincidental that the word "new" is incorporated in "news." The English word "news" has been around for more than five hundred years and is the plural form for "new." ${ }^{180}$ In some sense, this very concept is at odds with relevance to the extent that relevance is aimed at providing you with more of what you already know, appreciate, or like. Put another way, journalists are trained to look for the "man bites dog" story-the story that bucks the reader's expectation. ${ }^{181}$ Social media algorithms, in contrast, seem trained to play to those expectations.

To be sure, the press does not always comply with its own norms and conventions. Its lapses in transparency, truth, and accountability are well documented. ${ }^{182}$ The press has also long been criticized as elitist and, as citizens have gained easy access to the pathways of information, this criticism has gotten louder. ${ }^{183}$ The criticism has been particularly amplified in the wake of the 2016 presidential election. ${ }^{184}$ As Pariser has written in The Filter Bubble, the "ethos"

176. Id.

177. GAJDA, supra note 81, at 237.

178. Schudson, Why Democracies Need an Unlovable Press, supra note 38, at 48.

179. Id.

180. See News, The American Heritage Dictionary of the English Language (3d ed. 1992).

181. See Andrew Marr, The Making of Modern Britain 149 (2009) (describing how the phrase "When dog bites man, it isn't news; when man bites dog, it is" was coined by an editor of Britain's Daily Mail newspaper).

182. See, e.g., Michael Hiltzik, Stephen Glass Is Still Retracting His Fabricated Stories-18 Years Later, L.A. Times (Dec. 15, 2015, 12:47 PM), http://www.latimes.com/business/hiltzik/la-fi-mh-stephenglass-is-still-retracting-20151215-column.html [https://perma.cc/56UD-WFY7]. See generally EDWARD S. Herman \& Noam Chomsky, Manufacturing Consent: The Political Economy of the Mass Media (2002).

183. See Kovach \& Rosenstiel, supra note 113, at 7, 199.

184. See Kenneth P. Vogel \& Alex Isenstadt, How Did Everyone Get It So Wrong? Politico (Nov. 9 , 2016, 1:59 AM), http://www.politico.com/story/2016/11/how-did-everyone-get-2016-wrong-presidentialelection-231036 [https://perma.cc/A9NN-CUVC] (quoting a Republican operative who said, "Most of the press and folks in DC were science deniers when it came to this election .... Even in the face of polls that showed it very close, they all said that Trump had almost no chance. It was because they couldn't imagine it happening ... . [T] hey are in a bubble, and that bubble has just been burst."). 
of journalism has traditionally been that "[a]s newspapermen, it was their paternalistic duty to feed the citizenry a healthy diet of coverage." ${ }^{185}$ Some have argued that under this paternalistic model the press did a poor job of providing that healthy diet. For example, Ninth Circuit Judge Alex Kozinski has said: "In the days when the media and television in particular, viewed themselves as the guardians of our virtues and sensibilities, we lost touch with who and what we really are, mesmerized instead by some fun house mirror version of reality." 186 Some have argued that the very institutional nature of the press makes it ill-positioned to critique the establishment, including government officials. ${ }^{187}$

Yet, regardless of whether the press is elitist, or whether it is doing its job well, institutionally it has been guided by different principles than those that guide platforms, the new mediums by which news is delivered. As media and technology scholar Tarleton Gillespie has described it, competing forms of logic undergird journalism and algorithms. ${ }^{188}$ "[E]ditorial logic," says Gillespie, "depends on the subjective choices of experts, themselves made and authorized through institutional processes of training and certification." 189 In contrast, "algorithmic logic ... depends on the proceduralized choices of a machine, designed by human operators to automate some proxy of human judgment." 190 The differences in these principles have a powerful impact on our news ecosystem, both in terms of what content we consume and what we consider to be news.

\section{The Impact of a Change in Gatereeper}

Thus far, this Article has suggested that legacy news organizations and Silicon Valley-based platforms exist at opposing poles on a continuum. Although it is true that traditional journalistic norms are at odds with those of platforms, the platforms and their algorithms are actually forcing changes to the nature of the Fourth Estate and the news it produces. ${ }^{191}$ As Marshall McLuhan famously wrote in 1964, and as many have recounted since the Internet took

185. PARISER, supra note 109, at 59. Although, in Blur, Kovach and Rosenstiel argue that any charge of elitism is unfounded and "something of a myth." Kovach \& Rosenstiel, supra note 113, at 199-200.

186. Alex Kozinski, How I Stopped Worrying and Learned to Love the Press, 3 Comm. L. PoL'y 163, 173 (1998).

187. See Schudson, Why Democracies Need an Unlovable Press, supra note 38, at 84.

188. Gillespie, supra note 6, at 192.

189. Id.

190. Id.

191. This is evidenced even in the labels news organizations give themselves. For example, the 150-year-old Tribune Publishing Co., the owner of the Los Angeles Times and Chicago Tribune, recently rebranded itself as tronc, Inc. (a sort-of acronym for Tribune Online Content). See Lukas I. Alpert, Tribune Publishing Just Changed Its Name to 'tronc,' Wall ST. J. (June 2, 2016, 5:42 PM), https://www.wsj.com/articles/tribune-publishing-just-changed-its-name-to-tronc-1464903778 [https:// perma.cc/4F7Z-8976] (noting the change was "a nod to the publisher's transformation into a more digitally focused company"). 
hold: "[T]he medium is the message."192 In other words, the dominance of platforms and their algorithms as the mediums through which we get news is changing the news itself.

Until recently, consuming news involved a certain amount of serendipity. As viewers of the evening nightly newscast, we saw (and still see) stories on topics that interested us. Yet, sandwiched in between, was news on other topics that journalists deemed important but that might not otherwise have held our interest. ${ }^{193}$ The same goes for the newspaper. When we scan the front page, we may see headlines that call out to us, but there are other stories (perhaps on disturbing or dry topics) that a group of journalists and editors deemed important. We likely read some of these stories in addition to the ones that immediately catch our eye.

Some of the serendipity and randomness to our news consumption is disappearing as algorithms customize our news. ${ }^{194}$ Although our Facebook "friends" may point us toward things we would not have otherwise seen or read, and in their own way may serve as our "editors," "195 often those friends share our interests and sentiments and do not present us with material that makes us uncomfortable. In fact, at least one media scholar has argued that algorithms deprioritize information that challenges us. ${ }^{196}$ Moreover, Facebook users can choose to block content from their "friends." 197

192. Marshall Mcluhan, Understanding Media: The Extensions of Man 7 (1964); accord Nicholas Carr, The Shallows: What the Internet Is Doing to Our Brains 2 (2010).

193. See Pablo J. Boczkowski \& Eugenia Mitchelstein, The News Gap 3 (2013) ("Through most of the twentieth century, the strong market position of the leading print and broadcast news organizations enabled them to tell the public what they thought the public needed to know, despite their perception that the public preferred something else ... . To learn about a sporting event, a reader had to buy an entire newspaper.").

194. See Somaiya, supra note 88 ("Facebook is at the forefront of a fundamental change in how people consume journalism. Most readers now come to it not through the print editions of newspapers and magazines or their home pages online, but through social media and search engines driven by an algorithm.").

195. Eytan Bakshy, Rethinking Information Diversity in Networks, FACEBooK (Jan. 17, 2012, 11:00 AM), https:/www.facebook.com/notes/facebook-data-team/rethinking-information-diversity-in-networks/ 10150503499618859 [https://perma.cc/F7Y5-V8SM] (finding in a study published by Facebook that "online social networks may actually increase the spread of novel information and diverse viewpoints"); Journal Reports: Leadership, Facebook: Media Company or Technology Platform?, WALL ST. J. (Oct. 30, 2016, 10:22 PM), http://www.wsj.com/articles/facebook-media-company-or-technologyplatform-1477880520 [https://perma.cc/G7Z7-4D97] ("Because Facebook enables you to hear more voices in a day than you otherwise would hear, Facebook actually broadens the number and types and diversity of news sources you hear. And so in your news feed every day it's not just one news outlet. It's not just five people. It's a much broader array. People are exposed to more views rather than less."').

196. Pablo Boczkowski, Has Election 2016 Been a Turning Point for the Influence of the News Media?, NiemanLab (Nov. 8, 2016, 11:46 AM), http:/www.niemanlab.org/2016/11/has-election-2016been-a-turning-point-for-the-influence-of-the-news-media [https://perma.cc/3A2E-PVT8] ("In addition, the commercial priorities of a company like Facebook shapes the algorithmic logic of its News Feed: The happier we are, the more likely the ads shown to us will be effective, so the algorithm prioritizes information items that are consistent with our viewpoints.").

197. What Does It Mean to Unfollow Someone?, FАсевоок, https://www.facebook.com/help/ 190078864497547 [https://perma.cc/UQN4-7MQF]. 
The resulting phenomenon is known as a "filter bubble." Pariser, who coined the term, says that the filter bubble is "a unique universe of information for each of us" that has been created by "prediction engines, constantly creating and refining a theory of who you are and what you'll do and want next." ${ }^{198}$ Editors sitting around a long table are no longer the primary curators of our news. Instead, Pariser says, "[o]ur media is a perfect reflection of our interests and desires." 199

Although the filter bubble metaphor is helpful, it provides an incomplete description of the changes that algorithms have fomented with respect to news. It accounts for the way news is sorted per our predilections: the news most "relevant" to us becomes part of our unique bubble, and everything else is left outside of it. Yet, it does not account for the way algorithms exert pressure that is changing the nature of news. That is, journalists are shaping what they report and write so that it will please the algorithms, permeate as many filter bubbles as possible, and go "viral." ${ }^{200}$ As a report from the Tow Center for Digital Journalism stated: "Publishers are making micro-adjustments on every story to achieve a better fit or better performance on each social outlet. This inevitably changes the presentation and tone of the journalism itself." ${ }^{201}$

This shift has been facilitated by the wide array of metrics that are now available to and used by newsrooms to chart their coverage. ${ }^{202}$ Some newspapers used to shield their reporters from this information. As recently as 2011, The New York Times didn't provide reporters with information about how many readers were clicking on certain stories. ${ }^{203}$ Then-editor Bill Keller said: "We

198. PARISER, supra note 109 , at 9.

199. Id. at 12. To see the impact that algorithms are having and bring into high relief how this filtering works, The Wall Street Journal created a tool called "Blue Feed, Red Feed." Blue Feed, Red Feed, WaLL St. J., http://graphics.wsj.com/blue-feed-red-feed [https://perma.cc/TKL7-XEN4]. Users can click on a variety of changing topics, which have included things like "ISIS," "President Trump," and "Abortion," to see how, according to the newspaper, "reality may differ for different Facebook users" depending on their politics. Id. The creator of the project, Jon Keenan, noted the difficulty of trying to escape the effect of the algorithm. Ricardo Bilton, The Wall Street Journal's New Tool Gives a Side-by-Side Look at the Facebook Political News Filter Bubble, NiEMAnLaB (May 18, 2016), http://www. niemanlab.org/2016/05/the-wall-street-journals-new-tool-gives-a-side-by-side-look-at-the-facebookpolitical-news-filter-bubble [https://perma.cc/GQ66-DND2]. He said, "If you wanted to widen your perspective and see things from a broad range of backgrounds, you would have to go and like the pages yourself. Facebook's product makes it hard to do this." Id. In a related project, The Washington Post publishes an e-newsletter called "The World According to Facebook" in which it logs the stories that trend on Facebook, Google, and Twitter. See The World According to Facebook, Wash. Post, https:// tinyletter.com/the-intersect [https://perma.cc/5KX3-HLB5]. The site says that the effort aims to "venture into a sobering and not-so-alternate reality, where the news of the day is picked by algorithms we can't really see." Id.

200. See Mallary Jean Tenore, 10 Ways Journalists Can Use Twitter Before, During and After Reporting a Story, PoynTer (Sept. 20, 2011), http://www.poynter.org/2011/10-ways-journalists-can-usetwitter-before-during-and-after-reporting-a-story/146345/ [https://perma.cc/FP4F-LQK4] (describing Twitter as a way for journalists to "[f]ind \& capture reaction" to their stories).

201. BeLl \& Owen, supra note 89 , at 37.

202. See Rosenstiel, supra note 175.

203. PARISER, supra note 109, at 69. 
don't let metrics dictate our assignments and play... because we believe readers come to us for our judgment, not the judgment of the crowd. We're not 'American Idol.",204

In contrast, today The New York Times uses a tool called "Stela" to give reporters and editors quick data points, including the number of page views a story is getting and how often Twitter or Facebook posts of stories have been shared or retweeted. ${ }^{205}$ Steve Mayne, the paper's "lead growth editor" said that Stela represents something that is "part and parcel of what journalism should be: understanding your audience [and] how to reach them."206 The New York Times is not alone. Entire companies, like Chartbeat, exist to provide analytics aimed at helping media companies "capture social momentum" and "keep [visitors] coming back again and again.",207

That such tools are desirable and even necessary is a manifestation of what has been called "the news gap." "The news gap," a term coined by Pablo Boczkowski, director of Northwestern University's Program in Media, Technology, and Society, and Eugenia Mitchelstein, an Argentine professor, is the divide between what reporters want to cover and what their audience wants to read. $^{208}$ After analyzing approximately 40,000 stories posted on news sites based in North and South America and Western Europe, the professors found the gap to be significant ${ }^{209}$ : "Although the news organizations disseminate news about politics, international, and economic matters, the stories that garner the most attention from the public tend to be about sports, crime, entertainment, and weather." 210

It is also easy to find anecdotal evidence of the news gap. The Seattle Times's most read article in 2005 had to do with a man who died after having sex with a horse. ${ }^{211}$ Similarly, for the Los Angeles Times in 2007, it was an article about "the world's ugliest dog." 212 Even the most vaunted of publications are not immune. "The [New York] Times is now publishing articles it never would have touched before in order to stay a part of a conversation that's taking place on social media and read on smartphones," Margaret Sullivan, the former public

204. Jeremy W. Peters, Some Newspapers, Tracking Readers Online, Shift Coverage, N.Y. TIMES (Sept. 5, 2010), http://www.nytimes.com/2010/09/06/business/media/06track.html [https://nyti.ms/ 2pzIRiM]; see also PARISER, supra note 109, at 69-70.

205. See Shan Wang, The New York Times Is Trying to Narrow the Distance Between Reporters and Analytics Data, NiEMAnLaB (July 25, 2016, 12:44 PM), http://www.niemanlab.org/2016/07/the-new-yorktimes-is-trying-to-narrow-the-distance-between-reporters-and-analytics-data/ [https://perma.cc/Y7DGHNGC].

206. Id.

207. Chartbeat, How to Build an Audience That Reads What You Write and Comes Back for More: A Chartbeat Insider Guide 5, 8, http://lp.chartbeat.com/rs/062-HAC-076/images/Insider_Guide_ Audience_Building_final.pdf [https://perma.cc/3JMC-UMK8].

208. BocZKowsKi \& Mitchelstein, supra note 193, at 4.

209. Id. at $13-17$.

210. Id. at 2 .

211. PARISER, supra note 109 , at 72.

212. Id. 
editor of The New York Times, wrote in her final column for the paper. ${ }^{213}$ In 2015, the top "article" on The Times's website, ranked by the amount of time readers spent looking at it, was a thirty-six-question quiz designed to accelerate the intimacy between two strangers. ${ }^{214}$

And in some instances, journalists are handing their work entirely over to a formula. The Associated Press and Los Angeles Times have been pioneers in what has been called "robot journalism" or "automated journalism" in which algorithms actually write stories. ${ }^{215}$ The Associated Press announced in 2015 that it was automatically generating more than 3,000 stories per quarter about corporate earnings. ${ }^{216}$ The Los Angeles Times has created "Quakebot," which utilizes data from the U.S. Geological Survey's Earthquake Notification System to automatically generate stories about earthquakes that a human editor can quickly review before publication. ${ }^{217}$ In one instance, Quakebot resulted in the paper posting a story about a 4.4 magnitude earthquake within three minutes of its hitting Southern California. ${ }^{218}$ Yet, as a sign that robot journalism is far from perfect, in several other instances the newspaper has published stories based on faulty data about earthquakes that never occurred. ${ }^{219}$

213. See Margaret Sullivan, Public Editor No. 5 Is Yesterday's News, N.Y Times (Apr. 17, 2016), http://www.nytimes.com/2016/04/17/public-editor/margaret-sullivan-new-york-times-public-editor. html [https://nyti.ms/20Lor2c].

214. Daniel Jones, The 36 Questions that Lead to Love, N.Y. Times (Jan. 9, 2015), https://www. nytimes.com/2015/01/11/fashion/no-37-big-wedding-or-small.html [https://nyti.ms/2jAhy7m]. Bob Woodward has also spoken of the media's tendency to dish up to the public its thoughts, desires, and predispositions packaged as news. The Case Against the Media. By the Media, N.Y. MAg. (July 25, 2016), http://nymag.com/daily/intelligencer/2016/07/case-against-media.html [https://perma.cc/2FPW-B YBB] ("We're now in a media environment where [the media] will take a poll . . . and say, "What do you think now? Of the candidates or the controversies? Who do you trust? Who are you going to vote for? Who do you favor?' And what we're not saying to people is, 'We've provided you with lots of information, but maybe we haven't provided you with enough."). Similarly, it is reported that 60 Minutes creator Don Hewitt often said that a modern-day television network would have cancelled his show early on because of low Nielsen ratings. Id. It wasn't entertaining enough. See id.

215. See Andreas Graefe, Guide to Automated Journalism, Tow CTr. For Digital Journalism (Jan. 7, 2016), http://towcenter.org/research/guide-to-automated-journalism/ [https://perma.cc/XUD6-4LDV]; Damian Radcliffe, Did a Robot Write This Article? The Upsides and Downsides of Automated Journalism, BBC: ACAD. (June 23, 2016, 3:44 PM), http://www.bbc.co.uk/blogs/academy/entries/e327bbb3-4bf84083-82ae-2153665535b1 [https://perma.cc/U8SR-X8QK].

216. Radcliffe, supra note 215.

217. Graefe, supra note 215.

218. Id.

219. Id. Relatedly, beyond algorithms exerting control over the mainstream press, Facebook hosts its own brand of news. See John Herrman, Inside Facebook's (Totally Insane, Unintentionally Gigantic, Hyperpartisan) Political-Media Machine, N.Y. TIMEs MAG. (Aug. 24, 2016), https://www.nytimes.com/ 2016/08/28/magazine/inside-facebooks-totally-insane-unintentionally-gigantic-hyperpartisan-political -media-machine.html?_r=0 [https://nyti.ms/2k82R8I]. Sources like "Occupy Democrats," "RightAlerts," and "American News" have an audience of tens of millions and do not exist outside of Facebook. Id. Media writer John Hermann calls these sources "the purest expression of Facebook's design and of the incentives coded into its algorithm - a system that has already reshaped the web and has now inherited, for better or for worse, a great deal of America's political discourse." Id. The primary goal of these news sources is "not to get [the reader] to click on more stories or to engage further with a brand," he 
Even given the control that algorithms now exert on news, it is not true that public-service journalism is dead, that all journalists are writing to affect a Twitter spike, or that algorithms are poised to take over the jobs of journalists. ${ }^{220}$ Many journalists are still doing the type of shoe-leather journalism that Margaret Sullivan advocates. ${ }^{221}$ In some instances, these journalists work for entities like ProPublica that have sidestepped the disruption to media's funding model by organizing as nonprofits. But they also work for legacy news organizations. As just one example, the Pulitzer Prize for investigative reporting in 2016 went to journalists from the Tampa Bay Times and Sarasota Herald-Tribune for articles and video about violence and neglect in Florida mental hospitals. ${ }^{222}$ Yet, the viability of such watchdog journalism was in doubt even before the advent of algorithms simply because it is so expensive to produce. ${ }^{223}$ Add the concern that such work may not be as likely to be read, and there is even more cause for concern that this brand of journalism may wither further. ${ }^{224}$

writes. Rather, it is "to get them to share the post that's right in front of them. Everything else is secondary." Id.

220. See, e.g., Paul Bradshaw, It's Your Filter Bubble-Not Facebook's, Thoughts on Journalism (June 28, 2016), https://medium.com/thoughts-on-journalism/its-your-filter-bubble-not-facebook-s33d4f83e36ae\#.zbigjab4b [https://perma.cc/JUF5-63DQ] ("Designing serendipity into your workflow is now part of what makes a good journalist: curiosity expressed algorithmically. Design your way out of the filter bubble.")

221. See Sullivan, supra note 153 ("A real journalist is one who understands, at a cellular level, and doesn't shy away from, the adversarial relationship between government and press ....").

222. See Leonora LaPeter Anton et al., Insane. Invisible. In Danger. Florida Cut $\$ 100$ Million from Its Mental Hospitals. Chaos Quickly Followed, TAmpa Bay Times \& Sarasota Herald Tribune, http://www.tampabay.com/projects/2015/investigations/florida-mental-health-hospitals/ [https://perma. cc/A93W-ZMCU].

223. See Marc Andreessen, Why I'm Bullish on the News, Politico MAG. (May/June 2014), http://www. politico.com/magazine/story/2014/05/marc-andreesen-why-im-bullish-on-the-news-105921.html\#. Va5fUqa-u3A [https://perma.cc/HP2H-B8KX] (noting investigative journalism is "widely believed to be the least commercially viable type of news"); Monika Bauerlein \& Clara Jeffrey, This is What's Missing from Journalism Right Now, MotheR Jones (Aug. 17, 2016, 2:30 PM), http://www.motherjones. com/media/2016/08/whats-missing-from-journalism [https://perma.cc/QBQ5-QAR5] (noting an investigative piece on prisons by Mother Jones cost approximately $\$ 350,000$ and brought in approximately $\$ 5,000$ in banner advertising). Stanford economist James T. Hamilton, in a 2009 paper on subsidizing the news business, suggested that funding a beat reporter for a year in North Carolina would cost $\$ 61,500$, while funding an investigative reporting unit (including an editor, three reporters, research, travel and legal expenses) that might produce two or three investigative series per year, would cost $\$ 500,000$. See James T. Hamilton, Subsidizing the Watchdog: What Would It Cost to Support Investigative Journalism at a Large Metropolitan Daily Newspaper, Duke Conf. on NonProfit Media 3-4 (2009), www2.sanford.duke.edu/nonprofitmedia/documents/dwchamiltonfinal.pdf [https://perma.cc/ G3GB-Z66X].

224. BoczkowsKi \& Mitchelstein, supra note 193, at 5-6 ("Lack of interest in public-affairs topics may lead to a citizenry that is neither prepared nor willing to discuss these topics, and fragmentation of the audience may undermine the position of the media in the circuit of public deliberation. The gap may also be a disincentive for the leading media to perform their traditional watchdog function, by which they help to hold government officials and other large collective actors accountable. Since watchdog journalism is rarely cost effective for the organizations that undertake it, the gap may increase pressure for these organizations to reduce the resources they devote to it. That would shift the balance of power further in favor of large collective actors, to the detriment of social accountability."). 
Yet, despite the excellent journalism being done in many quarters, it cannot be denied that the process for determining what qualifies as news is shifting. For decades now that process has involved human beings sitting around a table hashing out what qualified as news. Today, algorithms armed with a bevy of information about each of us exercise a great deal of control over what news we see and, more and more, what news journalists choose to cover. As former columnist for The New York Times Frank Rich recently noted: "The power of Facebook to adjudicate what is news and what is not is extraordinary and, I think, unprecedented in the history of modern media.",225

\section{Rethinking Newsworthiness: Balancing Privacy and the First AMENDMENT}

In the news business, newsworthiness has changed. It is no longer true, as the Restatement says, that it can be determined from "a glance at any morning paper." ${ }^{226}$ Courts can no longer assume that editorial discretion and judgment about what to cover and how to cover it are always operating in the same way they once were. Instead, "algorithmic logic," is eclipsing "editorial logic."227 What we are consuming as news is far more likely to be that which is "relevant" to us than what journalists sitting around a table determined was "worthy" and "legitimate." As the Tow Center report succinctly put it, "good reporting is not currently algorithmically privileged on many platforms." ${ }^{228}$ Thus, today, it is not as self-evident as it once was that, in the words of New York's highest court, "questions of 'newsworthiness' are better left to reasonable editorial judgment and discretion." 229

Given the rift between traditional conceptions of newsworthiness and the reality of today's media landscape, there are a few options to consider. On one end of the spectrum is rejecting the newsworthiness concept altogether. Although decisive, this response is not particularly pragmatic given the entrench-

225. The Case Against the Media, By the Media, supra note 214. And although this Article focuses on the changes to news that flow from the predominance of algorithms, algorithms are not the sole force changing the nature of the Fourth Estate or its product. There are numerous others that are not addressed here in detail. One is the breakdown of the traditional boundaries between business and editorial sides of a newspaper and a related increase in "native advertising" — advertising that can appear to be news content. See Ellison, supra note 160 (quoting The New York Times executive editor Dean Baquet as saying that "there was a limit to how far we could go as an institution if the people who made the journalism and the people who made the money didn't talk some"). Another is the democratization of the press through the rise of bloggers and "citizen journalists" such that it has become increasingly difficult to determine who qualifies as a journalist. See RonNell Andersen Jones, Rethinking Reporter's Privilege, 111 Мich. L. REv. 1221, 1240-41 (2013). These changes, in combination with the Fourth Estate's genuflection to algorithms, all mean that the law's rationale for protecting the press needs to evolve.

226. Restatement (SECOND) of Torts at $§ 652 \mathrm{D} \mathrm{cmt}$. g (Am. LaW Inst. 1977).

227. See Gillespie, supra note 6, at 192 (using terms "algorithmic logic" and "editorial logic" and suggesting that the former is "perhaps supplanting" the latter).

228. Bell \& Owen, supra note 89 , at 52.

229. Finger v. Omni Publ'ns Int'1, 566 N.E.2d 141, 144 (N.Y. 1990). 
ment of the public disclosure of private facts tort in the common law. ${ }^{230}$ On the other end is the possibility of redefining newsworthiness and in so doing, narrowing its scope. Such an effort would, of course, broaden privacy protections and help to effectuate more of a balance between privacy and First Amendment interests. Yet, as will be explained in this Part, attempts to meaningfully limit the definition have proved problematic.

Instead, this Article proposes a path in between: that we shift focus away from the substance of newsworthiness and instead develop the process that courts use for analyzing it. Rather than necessarily treating newsworthiness as a question of law and quickly dismissing cases at the summary judgment or motion to dismiss stage, this Article suggests that newsworthiness only be treated as a question of law where a media defendant can make a showing that it engaged in a process for determining newsworthiness and that the publication enhances First Amendment values. If it cannot make such a showing, newsworthiness should be treated as a question of fact, and judges and juries could then take on some of the deliberation and debate that has more traditionally happened in newsrooms. This could involve employing expert witnesses and using multi-factor tests to assess newsworthiness. In this way, the judicial branch can help make up for, in some sense, the dampening of the Fourth Estate's ability to thoughtfully deliberate over what it publishes. This process would also lead to sounder justifications for deference to the press when that deference is granted.

\section{A. BEYOND ALGORITHMS: WHY SWEEPING DEFERENCE IS NOT JUSTIFIED}

Before concluding that wholesale deference is not always warranted and offering an alternative, this Article pauses briefly to examine justifications that courts have, at times, invoked for deference beyond trust in the journalistic process. These include efficiency, that the First Amendment prohibits any interference with the press, and that the Fourth Estate is an institution co-equal to the courts. As described below, each of these rationales is lacking in some key respect.

First, with respect to efficiency, it is inescapable that courts will make certain determinations to manage their dockets. Efficiency is the driver behind any number of legal rules. It is, for example, at the core of the Federal Rules of Civil Procedure and myriad local court rules regarding motion practice and trial. ${ }^{231}$ Yet, despite its upside, efficiency is not particularly intellectually satisfying. That is the case where the tension is so clear and the issues at stake so important as between the First Amendment and privacy.

230. See Richards \& Solove, supra note 15, at 1903-04.

231. See Fed. R. Civ. P. 1 (noting that the rules "should be construed, administered, and employed by the court and the parties to secure the just, speedy, and inexpensive determination of every action and proceeding"). 
In privacy tort cases, deference has served efficiency by sparing courts the task of messy (and time-consuming) line drawing. ${ }^{232}$ If a court can, on a dispositive motion, find that newsworthiness exists as a matter of law, the court can find for the media defendant and dispose of a case relatively quickly. At least one New York court has verified the existence of this pattern. In Gaeta v. Home Box Office, in which the cable television network aired a program showing the plaintiff's reaction to public nudity, a New York state trial court noted that "[n]early all of the reported cases" that had considered the newsworthiness exception to New York's right-of-privacy law "have been decided as a matter of law" on pre-trial motions. ${ }^{233}$ The court concluded that "[t]his result is not surprising, given the judicial deference paid to the media's editorial judgments." ${ }^{234}$ Yet, as the Gaeta court suggests, the effect of efficiency in privacy cases is that the plaintiff virtually always loses. Given that the efficiency almost exclusively benefits media defendants at the expense of plaintiffs, its soundness as a rationale for deference is suspect. It cannot be that efficiency alone is so important that it trumps valuing privacy claims.

Another rationale that has been invoked for deference is the suggestion that courts may not insert themselves into the editorial meeting. In other words, the editorial process is sacrosanct. For example, in Green v. CBS Broadcasting, Inc., a defamation and invasion of privacy case, a Texas federal trial court granted summary judgment to CBS when a woman and her daughter alleged an episode of 48 Hours had falsely made the mother out to be a "liar" and a "gold digger" and revealed that her daughter was a victim of a sexual assault. ${ }^{235} \mathrm{In}$

232. See, e.g., Cinel v. Connick, 15 F.3d 1338, 1340, 1346 (5th Cir. 1994) (affirming dismissal of privacy claim against television stations that had disclosed sexually explicit video involving a priest); Haynes v. Alfred A. Knopf, Inc., 8 F.3d 1222, 1230, 1234-35 (7th Cir. 1993) (affirming summary judgment for journalist and publisher who plaintiffs had argued revealed details of plaintiffs' sex life); Lowe v. Hearst Commc'ns, Inc., 414 F. Supp. 2d 669, 672, 674 (W.D. Tex. 2006), aff'd, 487 F.3d 246 (5th Cir. 2007) (dismissing case against newspaper that published article about a lawyer and his wife bilking several men out of tens of thousands of dollars by threatening to expose their affairs with the wife).

233. 645 N.Y.S.2d 707, 710 (N.Y. Civ. Ct. 1996).

234. Id. The California courts have also noted that summary judgment is a "favored remedy" in First Amendment cases, even when those cases involve privacy rights. See Shulman v. Grp. W. Prods., Inc., 955 P.2d 469, 486-87 (Cal. 1998); see also Smith v. NBC Universal, Inc., 524 F. Supp. 2d 315, 326 (S.D.N.Y. 2007) (relying on Shulman); Diane L. Zimmerman, Requiem for a Heavyweight: A Farewell to Warren and Brandeis's Privacy Tort, 68 CoRnell L. Rev. 291, 353-54 (1983) ("If the case law is any gauge, most judges share the Supreme Court's reluctance to engage in line drawing over newsworthiness and simply accept the press's judgment about what is and is not newsworthy. Although courts will occasionally find that a particular story is not privileged, the vast majority of cases seem to hold that what is printed is by definition of legitimate public interest."). It should be noted, however, that not all jurisdictions take this approach. In Massachusetts, for example, courts typically do not decide newsworthiness as a matter of law prior to discovery in a case. See Peckham v. New England Newspapers, Inc., 865 F. Supp. 2d 127, 131 (D. Mass. 2012) ("Indeed, as far as this court is aware, there is only a single instance in which a Massachusetts court, state or federal, made the determination that reasonable minds could not differ as to the newsworthiness of a particular publication at the motion to dismiss stage.").

235. Green v. CBS Broad., Inc., No. 3:98-CV-2740-T, 2000 WL 33243748, at *2, *11 (N.D. Tex. Dec. 19, 2000), aff'd sub nom. Green v. CBS Inc., 286 F.3d 281 (5th Cir. 2002). 
siding with the television network the court wrote, "Defendants' editorial decisions and newsworthiness judgments concerning the content of its broadcast are not subject to review by the courts." 236 The court relied on the Supreme Court's decision in Miami Herald Publishing and interpreted it to say that the First Amendment "prohibits governmental interference with the editorial decisions of the press."237

Yet, this reading of Supreme Court precedent is flawed. The Supreme Court has not decreed that the First Amendment always trumps privacy. In fact, it has gone to pains to say that privacy is fundamental and that in some circumstances it should prevail. ${ }^{238}$ Whether this is lip service is unclear. But if privacy torts are to survive, then it cannot be true that anytime a media entity is a defendant, the First Amendment outweighs privacy and deference to the media defendant is warranted. In such a situation, the newsworthiness exception would "swallow the tort." ${ }^{239}$ And so, to the extent that courts blindly follow authority to find that the press must win, either because it always has or the First Amendment mandates it, this rationale for deference should also fail.

Finally, deference to the press as a co-equal institution is also unsurprising given the long tradition of judicial deference to the institution most capable of a certain task. It is, in a sense, a close cousin of the efficiency rationale. The entity that has the best knowledge will act faster and better. This tenet underlies, for example, the standard of review in appellate $\operatorname{cases}^{240}$ and Chevron deference in

236. Id. at *7. This statement by the court was made in reasoning through the mother's defamation claim. The court granted the motion for summary judgment as to invasion of privacy finding that the daughter having been a victim of a sex crime was "generally known to many." Id. at *11.

237. Id. Less emphatic, but still highly wary of questioning the press, the California Supreme Court in Shulman indicated deference helped in "avoiding the likelihood of unconstitutional interference with freedom of the press to report truthfully on matters of legitimate public interest." Shulman, 955 P.2d at 484-86. While the court acknowledged that in "extreme" cases deference might not be warranted, it seemed that for all intents and purposes, the press was free to print what it pleased as long as it was truthful. Id. at 485,497 . To exercise a "supervisory power over the press" would be, in the court's words, "impermissible." Id. "The courts do not, and constitutionally could not, sit as superior editors of the press," it said. $I d$. at 488 .

238. See Florida Star v. B.J.F., 491 U.S. 524, 532 (1989) ("Nor need we accept appellant's invitation to hold broadly that truthful publication may never be punished consistent with the First Amendment. Our cases have carefully eschewed reaching this ultimate question, mindful that the future may bring scenarios which prudence counsels our not resolving anticipatorily.").

239. See Time, Inc. v. Hill, 385 U.S. 374, 383 n.7 (1967) (quoting Harry Kalven Jr., Privacy in Tort Law: Were Warren and Brandeis Wrong?, 31 L. \& Contemp. Probs. 326, 335-36 (1966)).

240. See Fed. R. Civ. P. 52(a)(6) ("Findings of fact, whether based on oral or other evidence, must not be set aside unless clearly erroneous, and the reviewing court must give due regard to the trial court's opportunity to judge the witnesses' credibility."); Anderson v. City of Bessemer City, 470 U.S. 564, 575 (1985). Typically, appellate courts defer to trial courts on findings of fact because the trial courts often heard witnesses and examined evidence firsthand. Id. at 575 ("When findings are based on determinations regarding the credibility of witnesses, Rule 52(a) demands even greater deference to the trial court's findings; for only the trial judge can be aware of the variations in demeanor and tone of voice that bear so heavily on the listener's understanding of and belief in what is said."). It is assumed that the lower court's knowledge of the facts is better and that assumption is formalized in a rule. See $i d$. In contrast, appellate courts review de novo issues of law based on the assumption that, as the 
the administrative law realm. ${ }^{241}$ And it is not unheard of for a court to defer to the expertise of private entities when it believes a business or institution may be better placed to make a decision. ${ }^{242}$ Yet, for the reasons described in Parts II and III, given the changes to the way news is created and distributed, it is no longer clear that the courts should be quick to assume that a media defendant is engaging in a traditional editorial process and, as a result, readily defer to the Fourth Estate.

And so, there are numerous reasons why the courts have historically exercised deference to the press in privacy cases. Yet today, none of the rationales outlined provides a particularly sound basis for deference.

\section{B. SALVAGING NEWSWORTHINESS: A DEFINITIONAL APPROACH}

The ongoing changes in the media industry have already been so dramatic that there is some reason to think that, in the age of algorithms, newsworthiness has become an unworkable concept. Warren, Brandeis, and Prosser likely never envisioned that formulas rather than professional journalists would be deciding what qualified as "news." Even before the Internet upended the media world, scholars questioned the doctrinal soundness of newsworthiness because of the near impossibility of coming up with a workable definition. ${ }^{243}$

For example, Diane L. Zimmerman wrote more than thirty years ago that "the process of defining 'newsworthy' information has practically destroyed the private-facts tort as a realistic source of a legal remedy." ${ }^{244}$ She argued that the difficulties of the concept were so inescapable, and the consequences of an unbridled definition so pernicious, that "preservation of even a small corner of the Warren-Brandeis tort" was not worth the risk. ${ }^{245}$ More recently, Neil M. Richards has argued that newsworthiness has been conceived of so broadly that the hurdles to finding liability against any media defendant—much less any

specialized and higher courts, understanding and interpreting the law is their bailiwick. See HARRY T. Edwards \& Linda A. Elliott, Federal Courts Standards of Review 23 (2007).

241. Chevron U.S.A. Inc. v. Nat. Res. Def. Council, Inc., 467 U.S. 837, 844 (1984) ("We have long recognized that considerable weight should be accorded to an executive department's construction of a statutory scheme it is entrusted to administer, and the principle of deference to administrative interpretations." (footnote omitted)). Similarly, courts grant "substantial deference" to prison administrators" judgments regarding the appropriateness of prison regulations. See Overton v. Bazzetta, 539 U.S. 126, 132 (2003) ("We must accord substantial deference to the professional judgment of prison administrators, who bear a significant responsibility for defining the legitimate goals of a corrections system and for determining the most appropriate means to accomplish them.").

242. See, e.g., Cede \& Co. v. Technicolor, Inc., 634 A.2d 345, 360-61 (Del. 1993), modified on reargument, 636 A.2d 956 (Del. 1994) (describing how courts defer to the judgment of business directors under the "business judgment rule").

243. See, e.g., Harry Kalven Jr., Privacy in Tort Law-Were Warren and Brandeis Wrong?, 31 L. \& Contemp. Probs. 326, 336 (1966); Eugene Volokh, Freedom of Speech and Information Privacy: The Troubling Implications of a Right to Stop People from Speaking About You, 52 StAn. L. Rev. 1049, 1094 (2000).

244. Zimmerman, supra note 234 , at 351 .

245. Id. at 362 . 
other defendant-are almost insurmountably high. ${ }^{246}$ Richards has concluded that the public disclosure of private facts tort is "largely unconstitutional" and suggests abandoning it in favor of other causes of action, such as trespass and breach of confidence, that may better protect privacy interests. ${ }^{247}$

These arguments have even more force today. If anything, the problems that Zimmerman and Richards chronicled have only worsened as algorithms increasingly impact the generation and distribution of news. As noted earlier, the Restatement's conception of newsworthiness as applying to virtually everything the press publishes is based on an understanding that the press is acting with deliberation and discretion. Yet, today's press is being pushed by algorithms to prioritize interest over importance and "relevance" above all else. It is ever more likely that "news" is what benefits the media's bottom line instead of what promotes First Amendment values. Yet, given how entrenched the public disclosure of private facts tort has become in common law and statute, it is highly unlikely courts will simply abandon it. ${ }^{248}$

In light of the sticking power of the tort, others have worked to try to salvage the newsworthiness test. They have returned to the project (begun by Warren and Brandeis and continued by Prosser) of trying to define the term. ${ }^{249}$ In one particularly compelling effort, Amy Gajda proposes rethinking the disclosure tort to provide a presumption of newsworthiness that is only overcome "in truly exceptional cases, when the degradation of human dignity caused by the disclosure clearly outweighs the public's interest in the disclosure." 250 Such a test, through its presumption, helps to address courts' concern that they not sit as super-editors. It also leaves open the possibility that the presumption can be overcome. According to Gajda, the concept of "human dignity" avoids "pitfalls from an overbroad definition for newsworthiness."251

Yet, there are potentially two problems with the test. ${ }^{252}$ First, it is unclear whether it would only apply to the media. ${ }^{253}$ If it did only apply to media, that would mean different defendants would be subject to different standards, which

\footnotetext{
246. See Richards, supra note 36 , at $378-82$.

247. Id. at 383-84.

248. See Richards \& Solove, supra note 15, at 1921-22 (noting that "prior to Prosser, the landscape of the tort law of privacy was one of vigorous growth and experimentation; after Prosser, tort privacy became rigid and static").

249. See Prosser, supra note 22, at 416-18; Warren \& Brandeis, supra note 21, at 216-17.

250. GAJDA, supra note 81, at 233.

251. See id.

252. Gajda herself notes another potential problem, which is that an "excessive focus on dignity to the seeming exclusion of information of public interest" has led some European Union nations to be "willing to give their citizens a right to control information about themselves." Id. at 235 (footnote omitted)

253. Gajda suggests it would apply only to the media when she writes that the definition "attempts to give news media support in close cases through a strong presumption of newsworthiness." Id. at 233. Yet, it is possible given technology that a private fact could be published and distributed widely by a single person or a nonmedia actor. And so, it also seems possible that defendants other than media entities would invoke the newsworthiness defense.
} 
is perhaps unfair - not to mention hard to apply given the difficulty today of determining who comprises the media. If not, we would be granting the tremendous benefit of a legal presumption to any defendant in a disclosure of private facts case.

The second and perhaps more important problem is that by narrowing the definition of newsworthiness, it necessarily leaves things out. This might include privacy concerns that are legitimate and important. Protecting "human dignity" seems aimed at shielding bodily revelations, for example, preventing the disclosure of nude photos or sex tapes. ${ }^{254}$ In fact, the examples Gajda uses to demonstrate the application of her test are the recent Florida case involving Gawker's posting of a Hulk Hogan sex tape and a case involving a film crew trying to capture the arrest of a prosecutor on child sex solicitation charges when the prosecutor commits suicide. ${ }^{255}$ She argues that in the Hogan case the presumption of newsworthiness would be overcome and that in the case of the prosecutor arrested on child sex solicitation charges, it would not. ${ }^{256}$

That means that the test may not be of as much help when applied to cases involving invasions of information privacy. ${ }^{257}$ Take, for example, Harris $v$. Easton Publishing Co., a Pennsylvania decision in which a newspaper published a column that described the process of a woman applying for welfare benefits. ${ }^{258}$ The article also noted that the woman had a 17-year-old pregnant daughter. ${ }^{259}$ While the woman's name was not included in the column, the court found that some in the community were able to determine her identity. ${ }^{260}$ Applying Gajda's test, does it offend human dignity to have it revealed that one is applying for welfare and has a teenage daughter who is pregnant? A Pennsylvania appellate court found for the plaintiff, ${ }^{261}$ but it is not obvious that this was the correct answer, and invoking the concept of "human dignity" does not neatly resolve the case. ${ }^{262}$

254. Gajda seems to indicate that these are, in fact, the focus of the "human dignity" language when she writes: "Publications that degrade human dignity could thereafter be described to include those that involve depictions of sex, nudity, deeply private or deeply embarrassing medical conditions, private expressions of grief, and other similar parts of humanness generally not exposed to others." See id.

255. Id. at 234.

256. $I d$.

257. "Information privacy" has been defined as privacy that is "the result of legal restrictions and other conditions, such as social norms, that govern the use, transfer, and processing of personal data." Paul M. Schwartz, Property, Privacy, and Personal Data, 117 Harv. L. Rev. 2055, 2058 (2004) (footnote omitted). Gajda includes among the things protected by her definition "private information that is generally protected by tradition in the United States," but it is not clear what this includes. See GAJDA, supra note 81 , at 233.

258. 483 A.2d 1377, 1381-82 (Pa. Super. Ct. 1984).

259. Id. at 1381 .

260. Id. at 1382,1385 .

261. Id. at 1381.

262. In fact, interestingly, this column does not appear to have been written by a reporter. See id. Rather, it was part of a "public service column" that the state Department of Welfare regularly wrote and sent to newspapers for publication. Id. It seems possible then that the court felt less obliged to defer 
In fairness, picking apart tests is far easier than devising them. It can be argued that any test is doomed to fail given the need for elasticity in the definition of newsworthiness that Warren and Brandeis spoke of in $1890 .{ }^{263}$ Any definition is just that, a definition, fixed and static. And newsworthiness, due to its slipperiness and ever-changing nature, may elude definition. Perhaps this is why, as Diane L. Zimmerman has argued, virtually all newly devised tests have fallen short. $^{264}$

\section{TOWARDS NEW PROCESSES FOR DETERMINING NEWSWORTHINESS}

Given the maddening nature of newsworthiness - that the concept is entrenched in the law and yet impossible to pin down-it may be futile to continue trying to define it in a fixed and immutable way. Rather than focusing on the substance of newsworthiness, energy may be better spent developing the processes courts use to assess newsworthiness. It is the journalistic process of assessing newsworthiness that is being weakened as algorithms exercise more control over the media, and it is that process on which many courts have relied in deferring to the media. Although no legal process can supplant the editorial one (judges and juries are not reporters and editors, and do not have the same expertise), we can attempt to ensure that careful deliberation occurs in the litigation process as it has traditionally occurred in newsrooms. This would be an improvement over the reflexive deference that has characterized the courts' decision making in this arena. To be sure, this proposal is not aimed at decreasing the number of cases in which deference is granted to the press, although this would likely be the result. Rather, its goal is to provide a more principled basis for the outcome of a case, whatever that outcome may be.

As noted in Part I, courts often like to resolve public disclosure of private facts causes of action as early on in the life of a case as possible. ${ }^{265}$ For example, the California Supreme Court called summary judgment a "favored remedy" because "unnecessarily protracted litigation would have a chilling effect upon the exercise of First Amendment rights." 266 This might be the right outcome if only First Amendment rights were at stake, but in disclosure of private facts cases, privacy is also at play. In these instances, not only does the need to dispose of cases not seem pressing, but the difficulty of drawing the line

to the media defendant in the case given that the media had such a limited role in the harm and perhaps did not exercise its discretion regarding newsworthiness beyond publishing the column.

263. See Warren \& Brandeis, supra note 21, at 216.

264. Zimmerman, supra note 234, at 355 ("Although we might not wish to leave the determination of newsworthiness to the unregulated judgment of publishers, the absence of any other sensible test may dictate a continuation of the practice. Courts' efforts to devise a better standard have met with little success." (footnote omitted)).

265. Id. at 293 n.5 ("In a survey of state case law [regarding public disclosure of private facts], the author found fewer than 18 cases in which a plaintiff was either awarded damages or found to have stated a cause of action sufficient to withstand a motion for summary judgment or a motion to dismiss.").

266. See Shulman v. Grp. W Prods., Inc., 955 P.2d 469, 487 (Cal. 1998). 
between free speech and the fundamental right of privacy also cries out for careful consideration. ${ }^{267}$

There are a number of ways to insert this deliberative process into courts' decision making. One is to avoid classifying newsworthiness as a question of law. When newsworthiness is a question of law, it becomes easier for a court to dispose of a privacy cause of action on a summary judgment motion. And, as demonstrated, courts are content to do this. ${ }^{268}$ In contrast, some courts have adopted a process that requires the judge to play a gatekeeping function and determine whether newsworthiness should be treated as a question of law or a question of fact for the jury. ${ }^{269}$ This approach, prompted by recognition of the newsworthiness defense's complexity, has led to some especially careful consideration of it.

One example is Peckham v. New England Newspapers, Inc., in which a newspaper published a photo of a car accident scene that showed the plaintiff, who was hit by a drunk driver, waving to his family as emergency personnel tried to extricate him. ${ }^{270}$ If the Massachusetts federal district court had wanted simply to find the accident newsworthy as a matter of law and dismiss the case, it needed to look no further than the Restatement for support. The Restatement includes accidents among its examples of newsworthy events. ${ }^{271}$ Yet, the court rejected this approach as too simplistic. It wrote that "the lines demarcating the boundaries of the newsworthy defense are not easily discerned"272 and that "'drawing the line between inviolable private information and matters of legitimate public concern' is a 'difficult task." ${ }^{273}$ It added that to draw that line on a "factually anemic record" would be "inappropriate."274

267. Some might argue that free speech should necessarily trump privacy given that the Constitution only explicitly protects the former. Yet, such an absolutist position completely forsakes privacy. See Daniel J. Solove, The Virtues of Knowing Less: Justifying Privacy Protections Against Disclosure, 53 Duke L.J. 967, 978 (2003) (describing how an absolutist conception of the First Amendment leaves no room for protecting privacy).

268. See Lowe v. Hearst Commc'ns, Inc., 414 F. Supp. 2d 669, 674 (W.D. Tex. 2006) (finding legitimate public concern as a matter of law and dismissing privacy cause of action noting that "the courts must refrain from invading the discretion of editors"); Goodrich v. Waterbury Republican-Am., Inc., 448 A.2d 1317, 1331-32 (Conn. 1982) (finding newsworthiness as a matter of law and deferring to media defendant).

269. See, e.g., Doe v. Gangland Prods., Inc., 730 F.3d 946, 959 (9th Cir. 2013) (applying California law); Virgil v. Sports Illustrated, 424 F. Supp. 1286, 1290 (S.D. Cal. 1976) (noting that "newsworthiness is an issue dependent on the present state of community mores and, therefore, particularly suitable for jury determination" but finding that reasonable minds could not differ on newsworthiness in this case); Y.G. v. Jewish Hosp. of St. Louis, 795 S.W.2d 488, 503 (Mo. Ct. App. 1990); Sheaffer v. Shippensburg Chronicle, 2 Pa. D. \& C.3d 662, 670-71 (C.P. Cumberland Cty. 1977).

270. 865 F. Supp. 2d 127, 128-29, 132 (D. Mass. 2012).

271. Restatement (Second) of Torts $§ 652$ D cmt. g (Am. Law Inst. 1977).

272. Peckham, 865 F. Supp. 2 d at 132.

273. Id. (quoting Bonome v. Kaysen, No. 032767, 2004 WL 1194731, at*3 (Mass. Super. Ct. Mar. $3,2004)$ ).

274. Id. One reason the court found the record to be anemic was that the complaint had alleged that the newspaper made the photo available for sale on "Tee-shirts, coffee mugs, and mouse pads," but provided no other detail. Id. at 131. It is likely that this claim of commercial exploitation led the court 
Instead, the Peckham court explained that judges "must make an initial determination as to whether 'reasonable minds could differ as to how the community would regard the publication at issue.",275 If reasonable minds could differ, then the court would be precluded from finding newsworthiness as a matter of law, the record would then be developed as the case proceeded, and the issue would ultimately go to a jury. ${ }^{276}$

A handful of other jurisdictions take a similar approach. ${ }^{277}$ In doing so, they reject the belief that only a judge can decide what qualifies as newsworthy. ${ }^{278}$ These courts have pointed out that juries may have a particularly important role to play in assessing newsworthiness, given that community mores and standards are considerations in the balance between privacy and free speech. As the Restatement notes in its comments: "In determining what is a matter of legitimate public interest, account must be taken of the customs and conventions of the community; and in the last analysis what is proper becomes a matter of the community mores.",279

Again, this approach has opened the door to a potentially more nuanced assessment of and appreciation for the newsworthiness defense. California courts have, for example, refused to dismiss a case brought by former players of a little league team whose photo was used by a cable television network to illustrate a story about the molestation charges brought against the team's coach, ${ }^{280}$ affirmed denial of summary judgment for a newspaper whose publishing of the name of a witness to a crime scene might have endangered her, ${ }^{281}$ and agreed that the newsworthiness of a plaintiff's sexual identity was properly before a jury because it was unclear whether the plaintiff had voluntarily assumed a "position of public notoriety." 282

An alternative to having a judge play a gatekeeping function would be to put the burden on the media defendant to make a showing that newsworthiness should be treated as a matter of law. This would involve media defendants offering up proof that the privacy invasion that is the subject of the lawsuit was the product of a newsworthiness determination and that it promotes First Amendment values. After all, if the First Amendment animates the newsworthiness defense, it seems fair to require a media defendant to demonstrate the First

to be circumspect about finding quickly for the media in this case. That does not mean that the more deliberate process the court used would not be helpful in cases where commercial exploitation was not alleged.

275. Id.

276. Id.

277. See Doe v. Gangland Prods., Inc., 730 F.3d 946, 959 (9th Cir. 2013); Y.G. v. Jewish Hosp. of St. Louis, 795 S.W.2d 488, 503 (Mo. Ct. App. 1990); Sheaffer v. Shippensburg Chronicle, 2 Pa. D. \& C.3d 662, 670-71 (C.P. Cumberland Cty. 1977); Hawkins v. Multimedia, Inc., 344 S.E.2d 145, 146 (S.C. 1986).

278. See Sheaffer, 2 Pa. D. \& C.3d at 670-71.

279. Restatement (Second) of Torts $§ 652 \mathrm{D}$, cmt. h (Am. Law Inst. 1977).

280. See M.G. v. Time Warner, Inc., 89 Cal. App. 4th 623, 626 (Cal. Ct. App. 2001).

281. See Times-Mirror Co. v. Superior Court, 198 Cal. App. 3d 1420, 1429 (Cal. Ct. App. 1988).

282. See Diaz v. Oakland Tribune, Inc., 139 Cal. App. 3d 118, 134 (Cal. Ct. App. 1983). 
Amendment value of the publication at issue. Among the ways in which a media defendant might demonstrate the First Amendment value of a piece would be to show that in publishing it, the media defendant was acting in the press's traditional First Amendment capacity as a "helpful teacher" of the citizenry, a "dialogue builder," and a "watchdog" over institutions. ${ }^{283}$ In doing this, the media entity could also walk the court through-via affidavits or testimony from editors and reporters- just how the newsworthiness determination was made.

This proposal seeks to avoid a potential pitfall of Gajda's presumption of newsworthiness-how to determine who might qualify as the "press" and thus as a beneficiary of this presumption. Under this Article's proposal, media defendants could self-identify. They could choose to take on the burden of making a showing that their publication furthered First Amendment values and that a deliberative journalistic process was employed. If they could do so, it would serve as an escape hatch of sorts from having newsworthiness determined as a question of fact by the judge or jury. It would allow for the continued efficient resolution of cases.

Assuming newsworthiness is treated as a question of fact, a way to steer fact-finders to a more principled assessment of newsworthiness would be to provide them not with a static definition of the term but with factors to consider in determining whether it exists. California courts, for example, employ a three-factor test to assess whether a disclosure was newsworthy. ${ }^{284}$ Factors include: "[T]he social value of the facts published, the depth of the article's intrusion into ostensibly private affairs, and the extent to which the party voluntarily acceded to a position of public notoriety." ${ }^{285}$ These factors require the judge or jury to think as a journalist does about the societal worth of the publication. ${ }^{286}$

A third way to flesh out the process for assessing newsworthiness is allowing expert testimony on the issue. Although expert testimony on ultimate legal questions is disfavored, and courts have rejected expert testimony on the newsworthiness of a revelation where newsworthiness was a question of law, expert testimony could be useful if newsworthiness was viewed as a question of

283. See Jones, supra note 18 , at 256-59. The media defendant should not be required show that the publication was "news" per se. As the California Supreme Court has said: "[N]ewsworthiness is not limited to 'news' in the narrow sense of reports of current events. 'It extends also to the use of names, likenesses or facts in giving information to the public for purposes of education, amusement or enlightenment, when the public may reasonably be expected to have a legitimate interest in what is published." See Shulman v. Grp. W Prods., Inc., 955 P.2d 469, 485-86 (Cal. 1998) (quoting ReStATEMENT (SECOND) of ToRTs at $§ 652 \mathrm{D}$, cmt. j (AM. LAw Inst. 1977)).

284. See Shulman, 955 P.2d at 482.

285. Id.

286. A general critique that could be leveled at my approach is that it involves balancing. But, as Daniel J. Solove has noted, a balancing approach has "largely prevailed" over free speech absolutism. See Solove, supra note 267 , at 981-82. 
fact. ${ }^{287}$ Gajda has suggested that "practicing journalists within [a] community who follow an ethics code" could serve as "independent, court-appointed experts when the judge's sense is that the case before the court is the exceptional one in which human dignity trumps news value."288 Under this Article's proposed model, the court might seek such expert testimony after it made its gatekeeping determination that reasonable minds could differ on a subject's newsworthiness or, alternatively, after a media defendant failed to demonstrate that it engaged in an internal deliberative process and that the publication had First Amendment value. The court could then hear firsthand how a journalist might think through the newsworthiness of a particular revelation. Alternatively, the parties could choose to employ experts to assist the jury.

Reliance on an expert would also help prevent the newsworthiness determination from unduly overlapping with the "offensiveness" and "private facts" elements of the claim. ${ }^{289}$ Robert C. Post has written that if the "customs and conventions of the community" become the measure of legitimate public concern, then the offensiveness and private facts elements of the tort become "superfluous." $290 \mathrm{He}$ adds that "[a]s a result the capacity of the news to make persons and events public would be completely subordinated to the civility rules enforced by the public disclosure tort." ${ }^{, 291}$ In other words, there is some danger in completely handing over the newsworthiness determination to a jury. The danger is that the jury would rely solely on community customs and conventions in arriving at its decision. An expert would help to ensure that there was context for understanding what it means to be of "legitimate" public concern.

Including a practicing journalist as an expert would also help to address the concern that no one entity-be it media or judge or public_can independently determine what is newsworthy. As Daniel J. Solove has written: "[O]ne cannot say that systematically, courts/juries and legislatures are better than the media at determining what is of public or private concern. Each type of entity has special abilities and faults." 292 Solove continues: "There is no single optimal decisionmaker, but the combination of all of these decisionmakers is preferable to the dominance of only one." 293 This proposal allows for a combination of decision

287. See Anderson v. Suiters, 499 F.3d 1228, 1237 (10th Cir. 2007) (finding that newsworthiness is the "ultimate question of law" before the court and that, as a result, expert testimony on it is improper).

288. GAJDA, supra note 81 , at 258. Yet, Gajda argues that newsworthiness should be treated as a question of law and includes the caveat in her proposal that it could apply "when allowed under the rules of evidence." Id. at 233, 258.

289. See Post, Constitutional Domains: Democracy, Community, Management, supra note 167 , at 83 .

290. Id.

291. Id.

292. Solove, supra note 267 , at 1007.

293. Id. at 1007-08. Solove's concern with the media is not necessarily due to any recent development but rather, because it is a single social institution, according it too much power is problematic. He writes: 
makers and helps to prevent the courts from potentially encroaching too heavily on the Fourth Estate.

To be sure, there are disadvantages to these proposals. For example, providing ready means of putting the question of newsworthiness in the hands of a jury may seem to fly in the face of concerns that algorithms (unlike traditional journalists) are slave to users' tastes. It is true that this proposal requires putting faith in the jury process, perhaps undue faith. And yet, the function of the jury in applying law to facts and determining what is of legitimate public concernimportantly, with the guidance of factors and a practicing journalist-is far different, far more formalized, and far more subject to checks than the decisions those same jurors may make in their private lives about what to click on and read in their Facebook News Feed. ${ }^{294}$

Another significant concern these proposals might raise is that they open the door to prolonged litigation and possibly more judgments against media defendants at a time when the traditional media is very much under siege and struggling to adapt its business model to the current economy. ${ }^{295}$ Today, many excellent journalists are doing important work in a time of industry tumult, economic uncertainty, public skepticism, and some outright hostility. ${ }^{296}$ That work needs to be supported and protected. Yet, as some media law scholars have argued, First Amendment absolutism also does not serve the press well. Amy Gajda convincingly made this point in her book The First Amendment Bubble. ${ }^{297}$ She explained that because some in the media have pressed for "boundless conception[s]" of newsworthiness, the result is "a First Amendment

Like most social institutions, the media is flawed. It is also tremendously powerful, and given this reality, it might not be wise to accord it deference. Thus, the media should not have a monopoly on determining what is of public concern. Ultimately, such an important decision is for all of society to make, not just one segment of society or one type of social institution.

Id. at 1008 .

294. It might also be argued that the changes to how news is made are so sweeping and continuous that perhaps we need to wait and allow for platforms to take on some of the responsibilities the press has traditionally shouldered. Although I am highly skeptical that platforms want to take on the role of the Fourth Estate (even though some are reaching out to journalists in more visible ways), a benefit of the procedural approaches outlined here is that they are common law-based and so, inherently malleable. See Benjamin Mullin, Campbell Brown on Filter Bubbles, Fake News and Facebook's Role in the News Industry, PoynTER (Mar. 23, 2017), http://www.poynter.org/2017/campbell-brown-on-filterbubbles-fake-news-and-facebooks-role-in-the-news-industry/453290/ [http://perma.cc/X28M-SUBM] (discussing the new role for Campbell Brown, a former CNN host, as Facebook's Head of News Partnerships).

295. See Erin C. Carroll, Protecting the Watchdog: Using the Freedom of Information Act to Preference the Press, 2016 Utah L. Rev. 193, 200-07 (2016) (describing disruption to the media's economic model); Jones, supra note 156, at 559, 561 (demonstrating that newspapers are no longer able to fund the litigation and legislation efforts that they have in the past).

296. See Michael M. Grynbaum, Trump Strategist Stephen Bannon Says Media Should 'Keep Its Mouth Shut,' N.Y. TimEs (Jan. 26, 2017), https://www.nytimes.com/2017/01/26/business/media/stephenbannon-trump-news-media.html [https://nyti.ms/2jChcKC].

297. See GAJDA, supra note 81, at 223 ("This is, therefore, not a time for First Amendment absolutism."). 
bubble, not unlike those seen in other contexts, such as housing, the tech industry, and financial markets, where heedless expansion ultimately proved unsustainable." 298 Rather than protecting the press at any cost, the courts need to exercise deference selectively and do so in a principled way.

\section{CONCLUSION}

Given the dominance of platforms like Facebook, the related influence of algorithms on how news is made, and specifically how algorithms are beginning to supplant editorial discretion and the editorial process, courts need to rethink their rationales for deference to the press. In the realm of privacy law, courts have long trusted the Fourth Estate to vet the newsworthiness of a subject before publishing so that the courts themselves did not have to. Today, that trust is becoming misplaced.

Perhaps newsworthiness is an unworkable concept, one that does not assist in striking the right balance between privacy and the First Amendment. Yet, given how entrenched Prosser's privacy torts have become in statute and common law, there is sense in trying to salvage rather than discard newsworthiness. Short of trying to redefine the concept, one way that courts and juries can provide sounder justifications for their decisions regarding newsworthiness is to follow a more deliberate process in arriving at those decisions. The goal is not to decrease the rate at which judgments favor the media, but to start to provide more robust support for the decisions that are made and to better address the justifiable concern that courts pay lip service to privacy. Media defendants should need to show that they rigorously determined newsworthiness and that the publication of a private fact has First Amendment value. Otherwise, we should look to a process that can help judges and juries distinguish between what the public is merely interested in and what is of "legitimate public interest," between what appears as "news" on digital platforms and what is truly "newsworthy."

298. Id. at 195 (referring also to the calls for a "boundless conception" of who qualifies as a journalist, which are, in Gajda's estimation, likewise contributing to the First Amendment bubble). 